\title{
Mapping ecological processes and ecosystem services for prioritizing restoration efforts in a semi-arid Mediterranean river basin
}

Mattia Trabucchia ${ }^{\text {a, }}$, a Instituto Pirenaico Ecología, IPE-CSIC, Spanish National Research Council Avda.Montañana 1005. Zaragoza 50192, Spain. 'Institut Méditerranéen de Biodiversité et d'Ecologie marine et continentale (IMBE), Aix-Marseille Université, CNRS, IRD, Univ. Avignon, Technopôle Arbois-Méditerranée, Bât. Villemin - BP 80, F-13545 Aix-en-Provence cedex 04, France (mattia.trabucchi@imbe.fr).

Patrick J. O'Farrell', 'Natural Resources and the Environment, Council for Scientific and Industrial Research, P O Box 320, Stellenbosch, 7599, South Africa.

Eduardo Notivol ${ }^{\mathrm{d}}$, ${ }^{\mathrm{d}}$ Centro de Investigación y Tecnología Agroalimentaria.

Agrifood Research and Technology Centre of Aragón. Avda. Montañana 930, Zaragoza, 50059, Spain Francisco A. Comín ${ }^{a}$, Instituto Pirenaico Ecología IPE-CSIC, Spanish National Research Council Avda.Montañana 1005. Zaragoza 50192, Spain

Corresponding author:

Mattia Trabucchi

Institut Méditerranéen de Biodiversité et d'Ecologie marine et continentale (IMBE), Aix-Marseille Université, CNRS, IRD, Univ. Avignon, Technopôle Arbois-Méditerranée, Bât. Villemin - BP 80, F13545 Aix-en-Provence cedex 04, France

e-mail: mattia.trabucchi@imbe.fr

Tel: $+35(0) 442908473$

Key words: Erosion; prioritization; spatial congruence; Spain; Aichi targets; ecosystem function 


\begin{abstract}
Semi-arid Mediterranean regions are highly susceptible to desertification processes which can reduce the benefits that people obtain from healthy ecosystems and thus threaten human wellbeing. The European Union Biodiversity Strategy to 2020 recognizes the need to incorporate ecosystem services into land-use management, conservation and restoration actions. The inclusion of ecosystem services into restoration actions and plans is an emerging area of research and there are few documented approaches and guidelines on how to undertake such an exercise. This paper responds to this need, and we demonstrate an approach for identifying both key ecosystem-services provisioning areas and the spatial relationship between ecological processes and services. A degraded semi-arid Mediterranean river basin in north east Spain was used as a case study area. We show that the quantification and mapping of services is the first step required for both optimizing and targeting of specific local areas for restoration. Additionally, we provide guidelines for restoration planning at a watershed scale; establishing priorities for improving the delivery of ecosystem services at this scale; prioritizing the sub-watersheds for restoration based on their potential for delivering a combination of key ecosystem services for the entire basin.
\end{abstract}




\section{Introduction}

Human use and manipulation of ecosystems has increased rapidly over the last century. Approximately $60 \%$ of ecosystem services worldwide are considered to be either degraded or used in an unsustainable manner (Millennium Ecosystem Assessment 2005). In Europe, the majority of ecosystems are degraded to the point where their ability to deliver valuable ecosystem services has been impacted (European Commission 2011). The European Union Biodiversity Strategy to 2020 recognizes the need to incorporate ecosystem services into land-use management, conservation and restoration actions (Aichi target 14, CBD 2011). If we are to retain remaining vital ecological functions and the essential ecosystem services they supply, trends in ecosystem degradation need to be halted and reversed through restoration actions (Global Footprint Network 2008; Comín 2010). Positive correlations have been observed by ReyBenayas et al. (2009) between the provision of ecosystem services and the improvement of biodiversity in restored ecosystems with respect to both degraded and reference ecosystems (in good ecological condition). Therefore restoration can be planned based on ecosystem service provision as an alternative approach to most common restoration approaches which focus on the recovery of biodiversity.

Taking advantage of this positive relationship, enhancing ecosystem service benefits through restoration requires the alignment of restoration objectives and ecosystem services. A growing number of case studies are emerging at different scales where this alignment is being attempted. For example, Coen et al. (2007) reviewed the set of ecosystem services that restoring filter-feeding communities as oyster banks can provide; Birch et al. (2010) assessed through cost-benefit analysis the value of restoring a set of ecosystem services under different scenarios of reforestation in four dryland areas of Latin America; Loomis et al (2000) used a willingness to pay survey to residents of a river basin in Colorado (USA) to estimate benefits and costs of restoring five ecosystem services, including restoration of erosion impacts; Nelson et al. (2009) confirmed the positive relationship between ecosystem services provision and biodiversity analyzing the value of ecosytem services in different scenarios of management and restoration of a river basin in Oregon (USA). Also the Millennium Ecosystem Assessment (MA 2005) attempted to address the lack of ecosystem service information required for decision making by promoting and assessing current knowledge, scientific literature and data. The findings of this global initiative gave rise to the creation of ecosystem service databases at regional, national and pan-national scale concluding that detailed spatial information is required to locate and quantify ecosystem services for integration into plans for management and restoration (MA 2005). 
Mapping has become a popular tool for achieving different environmental objectives and the

"visualization" of ecosystem services distribution (Hauck et al. 2013), including addressing outstanding policy questions in ecosystem management, such as where in a territory restoration should be prioritized to obtain the greatest benefits (Trabucchi et al. 2012a; Maes et al. 2012; Palmer et al. 2013)? Such information should allow for the prioritization of investments (Johnson 1995). However, in practice, the spatial prioritization of restoration actions requires overlapping the subject of restoration (the degrading factor to be eliminated, buffered or recovered) and the benefits of restoration actions (the ecosystem services) at appropriate spatial scales (the scale at which proposed restoration actions are efficient). Birch et al. (2010) adopted a local scale approach to evaluate the potential results of restoring forests in terms of ecosystem services improvement and economic benefits. With this approach, detailed areas of net benefit were identified; however substantial variation in values was recorded among study areas, demonstrating that ecosystem service values are strongly context specific. Moberg and Rönnbäck (2003) proposed to consider a landscape scale for restoration through the evaluation of ecosystem services and claimed to consider the complex interactions among the sub-systems forming a landscape. The Millennium Ecosystem Assessment advocated for the benefits of restoring ecosystems globally in terms of ecosystem services improvement and further social benefits (MA 2005). However, De Groot et al. (2010) identified a long list of remaining challenges for the integration of the concept of ecosystem services and values in landscape planning, management and decision making. One of these key challenges was how to map values (ecological, social and economic) so as to facilitate the use of ecosystem services in (spatial) landscape planning and design. Finally it is becoming evident that without a direct measurement of processes or surrogates that lead to the production of ecosystem services it can be very difficult to know if restoration actions are leading to the delivery of services (Palmer and Filoso 2009).

There is increasing evidence that the watershed scale is an appropriate scale for planning ecological restoration (Roni et al 2002; Palmer et al 2009; Khatami and Berndtsson 2013), as this is the scale at which intensive ecological processes and interactions take place. Also, the watershed is a common unit of management for land and water authorities in many countries (Zalewski and Wagner-Lotkowska, 2004). Planning restoration at watershed scale requires the prioritization of sites or sub-watersheds according to their potential for delivering benefits from the restoration efforts (Mitsch et al. 2001). This is especially relevant for Mediterranean ecosystems, which are characterized by high heterogeneity and provide society with a great diversity of ecosystem services (Martín-Lopez et al. 2009). Erosion is a major global 
ecological problem (Dotterweich 2013). Most Mediterranean watersheds are affected by erosion (GarcíaRuiz et al. 2013), which threatens ecosystem service provision (Trabucchi et al. 2012b). Identifying priority restoration sites for sediment retention and maintaining land suitability at a watershed scale is of major interest both in terms of the efficient allocation of limited resources and for recovering the benefits provided by ecosystems in good ecological state.

Our study advances our understanding of the prioritization of sites for restoration of ecosystem services (Menz et al. 2013). We demonstrate an innovative method for identifying priority areas in a degraded opencast mining area in a semi-arid Mediterranean river basin in NE Spain, through the combination of erosion data with five ecosystem services maps, namely: erosion control, maintenance of soil fertility, surface water supply, water regulation, and carbon storage in woody vegetation. We selected these five ecosystem services based on their susceptibility to be degraded through soil erosion and because they are surrogates of key ecological processes for ecosystem functioning and watershed management. We use publicly available datasets, such as census and remote sensing data, to develop methods replicable in other locations. This study provides a useful practical demonstration of how the assessment of ecosystem services can be integrated into restoration planning at a watershed scale.

\section{Methods}

\subsection{Study area}

The Martín River Basin is a 2,112 $\mathrm{km}^{2}$ watershed located in the south-central part of the Ebro River Basin in northeastern Spain (Fig. 1 left) at an elevation ranging between 143 and $1620 \mathrm{~m}$ above sea level. This region has a Mediterranean climate with an annual average precipitation level of $360 \mathrm{~mm}$, which is very irregular, both seasonally and inter-annually.

Soils of the Martín River Basin are mostly regosols (41\% of the basin area), which are homogeneously spread across the region and are composed of medium and fine-textured materials derived from a wide range of rock types. This soil is typical of eroding lands in arid, semi-arid and mountainous regions (Sánchez-Andrés et al. 2010). Rendsina-lithosol and cambisol are shallow soils with medium and finetextured materials; they cover $12 \%$ and $13 \%$ of the Martín Basin, respectively. Calcic yermosol, defined as a surface horizon usually consisting of surface accumulations of rock fragments ("desert pavement") embedded in a loamy vesicular crust and covered by a thin aeolian sand or loess layer, extends over $8 \%$ 
of the study area. The combination of soil type and substrate makes the soils prone to erosion, especially when combined with the mismanagement of land cover and steep slopes.

Forty five percent of the Martín River basin area is used for agriculture, most of it in the upper north part of the basin; a further $2 \%$ is regarded as unproductive (this includes towns and extractive areas). The remaining area 53\%, is wild land as shrubland, dry grassland, conifer and hardwood.

Dry agriculture and cattle breeding have historically been the most important social and economic activities in the Martín River Basin, with rural society taking shape around the agricultural and livestock cycles. Centuries of overgrazing and deforestation in this semi-arid region, which is also prone to land degradation by wind erosion (López et al. 1998), have resulted in poor and exhausted lands. The basin is comprised of two distinct regions (Fig. 1 left): the highlands $\left(764 \mathrm{~km}^{2}\right)$, which are located in the southern part of the basin at a mean elevation of $1100 \mathrm{~m}$, have a cold climate and are mostly covered by grasslandshrubland and conifer-hardwood vegetation; and the lowlands $\left(1374 \mathrm{~km}^{2}\right)$, which are located in the northern part of the basin at a mean altitude of $750 \mathrm{~m}$, have a drier climate and are relatively flat. Dry cereal cultivation dominates the lowlands ( $63 \%$ of its area), although aridity is a major limitation for plant growth and development in the region (Guerrero-Campo and Montserrat-Martí 2004).

The two regions are separated by two reservoirs: one is located in the Martín River (Cueva Foradada) and the other is in the Escuriza, a Martín River tributary (maximum water storage capacities 22 and 6 $\mathrm{hm}^{3}$, respectively) (Fig. 1 right). These reservoirs intercept sediments from the upstream area, and these sediments disturb the natural flow regime, altering river sediment dynamics downstream and consequently affecting riparian environments and their functions and services.

The abundant coal mining operations in the upper watershed of the Martín and Escuriza Rivers (17 active opencast mines) between 1950 and 2000 were the main socio-economic stimulus in the highlands of this region; however, these operations declined in the last two decades, and only three mines are currently operating. Unfortunately, opencast mining causes full removal of the topsoil, which leads to a drastic alteration of land surface morphology, among other environmental degradation impacts, and requires restoration under Spanish legislation (Mining Law). Most of these open mine zones were restored following successively improved restoration techniques (Comín et al. 2009), but these areas still show an extensive release of sediments (Trabucchi et al. 2012b). In Martín Basin slope is a key factor relating to 
erosion with high and very high rates in the central and the south parts of the basin, including the mine areas, and low rates in the mostly flat agricultural north area (Trabucchi et al. 2012b).

\subsection{Identifying and mapping key services in the basin}

The management of ecosystem services requires a deep understanding of their links to the processes that underpin them (Fu et al. 2013). Identifying and selecting key ecosystem services that are to be mapped for the management and targeting of restoration area should be based upon the related ecological problems within a study area and major economic activity of that region (Wallace 2007). As with many other Spanish basins, River Martín Basin has been repeatedly deforested, and erosion, because of natural phenomena or those linked to human activities as opencast mining, is the major environmental problem (García-Ruiz 2010) affecting the ecological functioning of the whole watershed. We selected a suite of vital ecosystem services (TEEB 2010) linked to major ecological functions of the basin which are threatened by soil erosion: water flow regulation, surface water supply, erosion control, carbon storage in woody vegetation, and maintenance of soil fertility. We chose to consider separately these two last services that can be labelled as climate regulation services (de Groot et al. 2002) (in soil and biomass) and use the approach of Egoh et al. (2008) to emphasize the presence of these services in agriculture and semi-natural areas. Additionally, we also included the potential for recreation/ecotourism services related to recreational-heritage activities that could be a major alternative, in times of economic crisis, or complementary socio-economic activity due to the presence in the basin of various paleontological and archaeological sites declared UNESCO World Heritage Sites. We quantified and mapped these water and carbon related services to guide the prioritization of areas for target restoration actions and for driving the adoption of best management practices in the basin. The methods adopted and data used for quantifying and mapping are presented here for each service (see Supplementary materials for more detailed explanation).

\subsection{Surface water supply}

Degradation of the landscape is believed to influence the delivery of water resources especially when inappropriate agricultural practices are held in semiarid environments, mainly overgrazing, cultivation, and irrigation (Le Maitre et al. 2007). Surface water supply relates directly to the quantity of water available for human use. Surface water supply or water provision is predominantly regulated by meteorological factors but it is also influenced by terrain features such as topography and vegetation 
cover, both of which determine the water balance of the ecosystem. Many studies used volume of water produced as the ecosystem service surrogate of surface water supply due to runoff positively correlated with water supply (Egoh et al. 2008). Following this approach, a raster dataset of total runoff was obtained from the Spanish Integrated Water Information System (SIA

http://servicios2.marm.es/sia/visualizacion/lda/recursos/superficiales_escorrentia.jsp). Data were extracted from this national dataset and used as a surrogate surface water supply. The raster layer was expressed in $\mathrm{mm} /$ year per $1 \mathrm{~km}$ resolution cell size.

In this region, reservoirs are considered high surface water supply areas and classified with very high value, due to their capacity to provide water for human uses, though this is despite the fact that most of this water comes from other ecosystems and that reservoirs are artificially constructed infrastructure.

\subsection{Water flow regulation}

Water flow regulation is an important service in semi arid areas because of the negative impact of erosion and flooding on downstream communities (Myers 1996) on both natural and man-made systems. Ecosystems can play a key role in regulating surface water flow, which is directly related to the water storage capacity of the ecosystem, the magnitude of the aquifer and characteristics of the vadose zone, the vegetation cover in terrestrial ecosystems and the water retention time in aquatic systems. Important ground water recharge areas typically have low surface runoff volumes due to their increased infiltration capacity and high water storage. These characteristics, along with other factors such as plant cover, also limit erosion (Sophocleous 2002). Water recharge areas for the entire Ebro Basin have been mapped by the water authority Confederación Hidrografica del Ebro and expressed in mm/year at $350 \mathrm{~m}$ resolution cell size (CHE http://iber.chebro.es/geoportal/index.htm) using the Curve Number (USDA-SCS 1972). Data for the Martín Basin were extracted and used in this research.

\subsection{Carbon storage in woody vegetation}

Forest Ecosystems exchange energy, water, and nutrients and, in particular, carbon (C) with surrounding ecosystems, and play a major role in the global $\mathrm{C}$ cycle. Forests are the second major terrestrial $\mathrm{C}$ sinks, have large $\mathrm{C}$ densities and sequester large amounts of atmospheric carbon dioxide $\left(\mathrm{CO}_{2}\right)$ (Lorenz and Lal 2010). The amount of carbon stored in woody vegetation and its fixation rate was mapped across a large region, which included the Martín Basin, by the Agrifood Research and Technology Centre of Aragon (CITA, unpublished 
http://www.aragon.es/estaticos/GobiernoAragon/Departamentos/MedioAmbiente/Areas/03_Cambio_clim

atico/06_Proyectos_actuaciones_Emisiones_GEI/estudio.pdf). This report focused on modeling different forest management alternatives for $\mathrm{CO}_{2}$ sequestration, such as woody vegetation, and understanding the role of forests as $\mathrm{CO}_{2}$ sinks. The method used estimates of biomass and $\mathrm{CO}_{2}$ conversion using allometric equations (Montero et al. 2005) and data on tree diameters measured during the National Forest Inventory (IFN3 2005). Allometric equations related the diameter of a single tree species to the dry matter existing in different fractions or parts of the tree, i.e., the trunk, roots, leaves and branches of three different sizes. The information, which was linked to the sampling points of the National Forest Inventory, was extrapolated to surface units using the comprehensive 1:50,000 Spanish Forest Map (developed in coordination with the Third Spanish National Forest Inventory). GIS data layers for storage and sequestration rate, expressed in metric tons of $\mathrm{CO}_{2}$ equivalent $\left(\mathrm{T} \mathrm{CO}_{2}\right.$-eq), were available for the Martín River Basin in this cited report. The GIS layers were extracted as a polygon layer and converted to a raster layer to facilitate calculation.

\subsection{Erosion prevention}

In general, Mediterranean soils are considered as the "most fragile part" of the system (Salvati and Bajocco 2011). This fragile part underpins the terrestrial ecosystems and its biodiversity, which produces the biggest part of the services necessary for human well being in the Mediterranean Basin (García-Ruiz et al 2013). Reduced erosion control service may result in increased sediment delivery to freshwater systems and degrades these systems (Gobin et al. 2004). Natural vegetation enhances erosion control and plays a vital role in ameliorating the impact of erosion on freshwater systems (Reyers et al. 2009). Trabucchi et al. (2012b) mapped erosion risk in the Martín Basin (expressed in ton $\mathrm{ha}^{-1} \mathrm{yr}^{-1}$ ) using the RUSLE model (Renard et al. 1997). To extrapolate vegetation percentage cover, we used the cover factor of the RUSLE model, called the C factor (see Appendix 1), which is the cover-management term that represents the prior land use, crop canopy and surface cover (Renard et al. 1991) of our study area. Following the methods of Egoh et al. (2008), erosion control was mapped as a function of vegetation cover $(\%)$ and soil erosion estimates divided in five categories (from very low to very high). Based on these data, vegetation cover densities were distributed in three classes: 0-30\%, 30-70\% and 70-100\% (Quinton et al. 1997). Areas with vegetation cover greater than $30 \%$ and classified as having a very low to low erosion value were defined as having a potential to retain soil. An erosion control hotspot was defined as having a plant cover density greater than $70 \%$ with very low to low erosion values. Zones with 
cover densities of less than $30 \%$ and high to very high soil erosion values were extracted and identified as erosion-prone areas.

\subsection{Maintenance of soil fertility}

Accumulation of soil organic matter is an important process for soil formation especially in semi arid conditions where organic matter dynamics are limited and can be easily altered by habitat degradation and transformation (de Groot et al. 2002; Yuan et al. 2006). Organic carbon content (OCTOP) (\%) in the topsoil layer $(0-30 \mathrm{~cm})$ was mapped by Jones et al. (2005) for the European Soil Database using a $1 \mathrm{~km}$ resolution grid cell. Data were expressed as a percentage weight of organic carbon in the surface horizon by combining refined pedotransfer rules with spatial-thematic data layers of land cover and temperature. We used these data as a surrogate measure for the supporting ecosystem-service maintenance of soil fertility. Areas with a high organic content (>3.45\%) were classified as hotspots.

\subsection{Potential recreation and ecotourism}

Landscape as a visual experience holds considerable societal value. For rural tourism, the landscape is often the main attraction and can add significantly to the quality of life of the surrounding residents (Brabyn and Mark 2011). Since the end of the last century, many efforts have been made to promote tourism in the study area, which is rich in both natural and cultural resources. The basin is popular for its wide open spaces, scenery and the presence of the Martín River Cultural Park (http://www.parqueriomartin.com/en/), which is rich in both cultural heritage, including cave paintings, Iberian settlements and historical monuments, and natural sites, including caves, ravine waterfalls and mountain peaks. All of these cultural and natural sites are on hiking and mountain biking routes. The track locations were downloaded from Wikiloc (2011) and from the official web page of routes in Aragon (Senderos de Aragon 2011). Then we generated their viewsheds in a geographic information system (Environmental Systems Research Institute 2008) which are the elements visible to the human eye walking along the routes which is important for providing an attractive visible environment for tourists (Reyers et al. 2009). The resultant maps were included as hotspot production areas following the methodology of O'Farrell et al. (2010).

\subsection{Mapping spatial distribution of services and hotspots at basin and sub-watershed scale.}


Maps of the selected ecosystem services were created following the methods of Egoh et al. (2008) and

O'Farrell et al. (2010). In this study, data on surface water supply, flow regulation and maintenance of soil fertility had spatially continuous values that covered the whole basin, while data on the other services had spatially discrete values (e.g., the woody carbon storage layer was limited to forested areas and all other values were considered to be 0 ).

Each original map of the ecosystem services was reclassified into five classes that were determined using a Natural Breaks Jenk's (O' Farrell et al. 2010) which is a data classification method designed to determine the best arrangement of values into different classes. This is done by seeking to minimize each class's average deviation from the class mean, while maximizing each class's deviation from the means of the other groups. The features are divided into classes whose boundaries are set where there are relatively big differences in the data values (Environmental System Research Institute 2008).These five classes were renamed as very high, high, medium, low and very low. We assigned the value of 0 to the very low class of surface water supply, flow regulation and maintenance of soil fertility to avoid overlapping these services for the entire area because insignificant values mask potentially interesting results. The rest of the services of our suite have not been modified because they have a lower spatial distribution and include areas with no service flow at all (e.g., carbon storage is limited only in forested areas). Finally, service layers were overlapped one by one creating a service richness layer (with values between 0 and 6), and overlapping percentages were used to describe the spatial relationships between these services.

Hotspot maps were created for every single ecosystem service to identify, manage and conserve high service flow areas by extracting high and very high service values. In addition, multiple hotspot zones among services were identified and established by overlapping the hotspot layers of each of the different services following the methods of Egoh et al. (2008). Services were then generalized to the fourth order catchments, which attempted to highlight the richness of services in every sub-watershed by defining areas of land that are drained by a stretch of river of lower order than the main Martín River system. Sixty seven sub-watersheds were distinguished in the Martín Basin. To identify service values for the subwatersheds (Fig. 2 Left), we utilized basin service maps using the GIS Spatial Analyst-Zonal Statistic tool (Environmental System Research Institute 2008) and selected the majority statistical option (ArcGis resource center 2012), which determines the value that occurs most often out of all cells in the input in_value_raster that belongs to the same zone as the output cell. In our case, the majority statistical option 
attributes to every sub-watershed the most frequent value of overlapping services for all of the cells in that sub-watershed. When equal numbers of cells within a sub-watershed received the highest and the second highest value, the lower value was assigned to the sub-watershed. Despite this limitation, it is still considered to be the best statistical option for creating a general overview. Following this overview for the whole Martín Basin (Fig. 2 left), the extraction of detailed overlapped-services maps (Fig. 3 left) at the sub-watershed scale was conducted.

The same Zonal tool using the statistical majority option was applied at a sub-watershed scale to select hotspot sub-watersheds by the number of overlapped hotspot services (Fig. 3 Right).

This process of downscaling facilitates the selection of areas in the region that are particularly vulnerable to environmental degradation and have a high supply of ecosystem services. We extracted from the erosion map generated by Trabucchi et al. (2012b), the mean erosion value for every sub-watershed of the basin using zonal statistics with GIS. We then reclassified the erosion values and generated a new degradation map. Reclassification of this map was based on 'safe minimum standard of conservation' (SMS). SMS refers to an ecological threshold (Groffman et al. 2006) beyond which ecosystem changes may be irreversible (Schneiders et al. 2012).In our case, thresholds for soil erosion in the study area defined as: light (0-12 $\left.\mathrm{t}^{-1} \mathrm{ha}^{-1} \mathrm{yr}^{-1}\right)$ (Rojo 1990), medium (12-17 $\left.\mathrm{t}^{-1} \mathrm{ha}^{-1} \mathrm{yr}^{-1}\right)$ and high $\left(>17 \mathrm{t}^{-1} \mathrm{ha}^{-1} \mathrm{yr}^{-1}\right)$ (Moreno-de las Heras et al. 2011) degradation level (Fig. 4 right). This allows us to label sub-watersheds according to the provisioning of ecosystem services and degradation status, establish a relative ranking of priorities for restoration actions to recover lost and degraded ecosystem service provisions. Table 1 includes the criteria to prioritize sub-watersheds for restoration based on the combination of ecosystem service delivery and environmental risk of erosion.

\section{Results}

\subsection{Ecosystem service provision and spatial distribution.}

Water flow regulation, surface water supply and maintenance of soil fertility are all widespread services that cover approximately $79.5 \%, 67 \%$ and $61.5 \%$ of the study area, respectively (Table 2). Recreation and ecotourism covers $36 \%$, erosion control covers $27 \%$ and carbon storage in woody vegetation covers $21.1 \%$. 
Water flow regulation has the largest hotspot area, which is defined as the percentage of an area where a

(Table 2). Water flow regulation is governed by rainfall distribution but is strongly influenced by permeable, underlying geology, which is high in the mostly porous soils of the southern part of Martín Basin and facilitates groundwater recharge.

Surface water supply spread throughout the greater part of the basin. The highest values are located in the southern region and coincide with low values of maintenance of soil fertility.

Carbon storage and erosion control depend on the density of canopy cover and are mostly distributed according to an altitudinal pattern. Higher values correspond to a range of 600-1100 m above sea level. At higher altitudes, both services decline to intermediate values. Certain riparian areas defy this altitudinal trend, having high values for both of these services and showing no relationship to altitude (Fig. 1 Appendix).

Maintenance of soil fertility is predominantly found in the southern part of the study area, with very low or negligible values identified as one progresses towards the northern lowland flat areas of the basin.

Recreation and ecotourism services are found in some sub-watersheds located in the southern-central and northern-central part of the basin along the river system. Many hiking and mountain biking routes start near the towns of Albalate del Arzobispo, Montalbán and Utrillas and they extend towards semi-natural areas.

\subsection{Relationship between services}

The greatest overlap of services (3-5 services) was observed in mountainous areas of the south and central parts of the Martín Basin where dense plant cover, woodland and scrubland are located (Fig. 2 left). A relatively small part (14\%) of the Martín Basin is not delivering any of the selected suite of services. One and two services are provided in $25 \%$ and $25.8 \%$ of the basin area, respectively, and three services are provided in $21 \%$ of the area (Fig. 2 left).

The spatial overlap among services is high in general. The maximum overlap between services was found between surface water supply and water flow regulation and accounted for $65 \%$ of the basin area. The percentage area of the basin with overlapped hotspots of these two services was $6.75 \%$ and was located in 
the southern region (Fig. 2 right). The erosion control and water surface-supply overlap areas accounted for $3.5 \%$ and had an overlapped hotspot area of just $1.95 \%$ of the basin, which was associated with forest ecosystems. Recreation and ecotourism services have a relatively high overlap with water flow regulation but a small overlap with other services, such as carbon storage and erosion control (Table 3).

The map of overlapped hotspot services generated using high and very high values for all of the services shows that a region comprising only $0.12 \%$ of the mapped areas incorporated all 6 services. The area is located in the southern part of the basin and corresponds with conifer forest (Fig. 2 left). Conversely, $41 \%$ of the basin, mostly in the northern part, is not delivering high or very high values for any service. Most of the areas classified as hotspots delivered one service (25.9\%), two services (19\%) and three services (9.2\%). Only a small portion (0.71\%) delivered five (Fig. 2 right).

\subsection{Sub-watershed classification according to ecosystem service provision}

Applying the Spatial Analyst tool and the majority statistic option within the Zonal statistic module used to identify the greatest number of services found within each sub-watershed, we did not find a subwatershed that provided all six services.

The highest number of services observed in a sub-watershed was five and were found in three subwatersheds (no. 53, 61 and 62; see Fig. 3 left) located in the southern part of the basin, representing 3\% of the basin area. They were also located in areas classified as having low and medium levels of degradation (Fig. 4 right).

Sub-watershed number 62 represents a focal point for surrounding sub-watersheds that deliver at least 3 services (Fig. 3, left). In between the southern and the central part of the basin, nine other sub-watersheds deliver at least three services (no.25, 22,34,40,41,42,48,54 and 12) and account for 7\% of the total area. Nineteen sub-watersheds deliver two services and account for $36.6 \%$ of the basin area. Most of these sub-watershed corresponded with a low degraded status, and only sub-watershed 48 and 54 were classified as having a medium degradation level (Fig. 4 right). In contrast, most of the sub-watersheds in the northern part of the basin (13 sub-watersheds) were delivering just one service, which was most commonly surface water regulation.

\subsection{Hotspot services at sub-watershed scale}


Only four sub-watersheds were classified as hotspots and included up to four services within their right). Sub-watersheds 63 and 65 incorporate a vast mined area which has been restored (Fig. 1 left), but is still classified as highly degraded, whereas sub-watershed 61 is mostly covered by conifer and hardwood and has a medium degradation level. All of these sub-watersheds are found on steep slopes. In the same part of the basin, there are other sub-watersheds $(53,55,59,52$ and 62$)$ that supply three services and mostly fall into the low and medium degraded level (Fig. 4 left)

\section{Discussion}

\subsection{Value of the approach}

The presented approach allows for prioritizing restoration at a watershed scale selecting areas according to the ecosystem services they deliver in conjunction with an area's risk of environmental degradation, the erosion factor. This is a substantial shift in focus for restoration and management planning. Usually, restoration actions were predominately planned at an ecosystem scale, using reference ecosystems to define restoration actions and success (SER 2004) not taking into the mosaic nature of ecosystems. Using the combined evaluation of multiple services enables one to maximize the provision of multiple services according to the mosaic of ecosystems that make up a region (Aronson et al. 2006). The evaluation and categorization of different ecosystem services is based on two factors: the consideration of multiple ecosystem services and the approximation of the value of ecosystem service to obtain zones where high and very high values of services overlapped, which increases the importance of the selected zones. The inclusion of multiple ecosystem services, particularly those that are threatened by soil erosion and are also strongly related to key ecological processes and ecosystem functions, provides a more complete understanding and a stronger basis for making comparisons between zones (Swift et al. 2004; Carpenter et al. 2009; Palmer and Filoso 2009). Targeting restoration prioritization at a basin scale is significant because basins are mosaics of ecosystems, and most restoration plans focus on single ecosystem types (Palmer 2009a).

Our analysis focused on several ecosystem services based on ecological processes and characteristics that are the most significant for sustaining the ecological functions of a basin threatened by soil erosion. Most of these services are regulating services that enhance ecosystem resilience, and many have a synergy with provisioning (i.e. maintenance of soil fertility) and cultural services (Bennett et al. 2009). While we acknowledge that many other cultural aspects and values exist within this region, the selected tourism 
routes and viewsheds capture the potential for attracting visitors and providing socio-economic benefits to the local populations, which are key factors for socio-economic development and could have a major regulating impact on the area.

It's clear that our results need to be supported by additional socio-economic data to support and define more precise future decisions about management and restoration actions in the study area. However, the approach presented here is a method to prioritize zones for restoration in a watershed with the objective of recovering the provision of ecosystem services damaged by a major impact factor. Also this approach can form the basis for more comprehensive studies that will include a stakeholder perspective to understand which services are important for sustainable development in the basin (Forsyth et al. 2012).

A critical issue in mapping ecosystem services is data quality and availability. Mapping involves GIS overlay analysis and geoprocessing to combine input layers from diverse sources to derive the final ecosystem service map. Difficulties encountered with deriving ecosystem service maps relate to the scale, age and accuracy of the input layers (Troy and Wilson 2006). An appropriate level of precision is vital if the final spatial outputs are going to direct restoration and management. In our case, maintenance of soil fertility and surface water supply maps had a large cell-size unit $(1 \mathrm{~km})$ and these should be re-sampled at $20 \mathrm{~m}$ to direct further detailed analysis. Comparability of data is essential to meet the goal of establishing priority areas and objectives for restoration and land-use management.

\subsection{Trade-offs between services}

High values of some ecosystem services, especially provisioning services, are sometimes inversely related to other services, which challenges the sustainable use of the whole basin (Bennett et al. 2009; Viglizzo et al. 2011). Our results show that most of Martín Basin is important for the delivery of at least one service within our selected suite of services. Only a few small areas produce very high numbers of services. The high degree of clustering between services points to a synergistic relationship between most of the services selected, and this has also been highlighted by other studies (Naidoo and Ricketts 2006; Nelson et al. 2009). As expected, the areas important for carbon storage, maintenance of soil fertility, erosion control and water flow regulation were clustered with different overlapping percentages. It is well known that trees stabilize soil with their roots, contribute to organic carbon accumulation due to the formation of leaf litter and facilitate water infiltration and storage, which facilitates plant-growth with 
consequent increase in the storage of carbon (Winjum and Schroeder 1997; Durán Zuazo and Rodríguez importance was not included in our study because we were focusing on management and restoration of semi-natural ecosystems. But the very low values of soil fertility in the north part of the basin suggests a possible trade off with food production, and many studies in conventional agriculture have already shown this inverse relationship (Matson et al. 1997; Bellot et al. 1999; Power 2010). However, it is not always valid to say that a territory rich in services has a good ecological status. If restoration focuses on just one service, trade-offs among services can create declines in some ecosystem services (MA 2005; Tallis et al. 2008) and could lead to negative impacts on biodiversity or provisions for other services. Use of suitable indicators for quantifying ecosystem services at a regional scale is challenging because major ecosystem services vary across different ecosystems. Too many indicators may confuse the public and decision makers, while too few will invalidate the results (Su et al. 2012). It is important to select or develop indicators that reflect the potential of the system to sustain the yield of each service (McMichael et al. 2005). When planning restoration, considering a number of ecosystem services with the intent of improving the balance of the selected services and considering the threat factor for these services, is an objective-based strategy that offers a long term benefit to the whole socio-ecological system rather than just to a few structural and functional ecosystem characteristics (Kremen and Ostfeld 2005; Palmer et al. 2009). An example of this is the case presented by Barbier et al. (2008) that demonstrates the negative, long-term socio-ecological impacts after the conversion of mangroves to shrimp farming. Another example is the case of using alien species monocultures for cellulose production (Eucalyptus), which causes a reduced water yield from catchments among other service trade-offs (Samraj et al. 1988).

\subsection{Guidelines for the Martin watershed management and restoration}

Using this approach, we were able to identify sub-watersheds located in the northern part of the lowlands of Martín Basin that only supplied one service or contain very low values (i.e. maintenance of soil fertility and surface water supply) of our suite. There were 24 sub-watersheds marked in this area, representing $39.5 \%$ of the basin area. Most of these (13) did not provide one ecosystem service or very low values and eleven of these sub-watersheds provided only one to two services (Fig. 3 Left). Conversely, subwatersheds that delivered several ecosystem services, in many zones with high values, were located in the 
southern part of the basin in the highlands, which is also the area where major impacts of mining activities originate.

These results suggest that alternative decisions must be considered regarding the spatial allocation of restoration actions at the basin scale. Is it better to restore services in the northern part of the basin, which currently, with the ecosystem services considered, provides mostly just one service, and manage this part of the basin to enhance multiple services simultaneously? Or, is it better to restore impacted and degraded areas in the southern part, which are already providing high values of multiple services, because of their importance in assuring the continuous delivery of services?

Placing the major restoration emphasis on the southern region would improve ecological functions as erosion is a major detractor in the provision of ecosystem services, negatively affecting erosion control, surface water supply, and the biodiversity based services. Adopting this strategy would increase the delivery of ecosystem services throughout the entire basin because the lowlands depend on ecological processes taking place in the highlands. For example, some surface water supplied in the highlands may become available in the lowlands due to run-off, infiltration or human-managed systems acting as reservoirs and canals. The six services that we have focused on have high values in the highland area of the basin, and their proper maintenance will stimulate synergies among services ameliorating the flow of services throughout the basin. In addition, the northern lowlands are dominated by agricultural production. Prioritizing restoration in the lowland region of the basin would compromise the benefits obtained from extensive agricultural farming and would likely affect the positive social atmosphere required for producing an efficient restoration project. This region largely includes very low values of some service like the maintenance of soil fertility, it is important to consider alternative land use management approaches and strategies in these areas which could directly increase this key service and thereby trigger a positive feedback with the majority of the services included in our study (Lal et al. 2013).

The marked spatial heterogeneity of this basin largely governs the distribution of ecosystem services. Our findings highlight the need for an integrated approach to land-use management and restoration prioritization. This is particularly relevant in watersheds with large agricultural areas (Zhang et al. 2007) and/or where intensive extractive activities, such as mining, are of key economic importance for the population of the region. Integrative strategies should focus on enhancing ecosystem service delivery through restoration of hotspots or sub-watersheds that offer high numbers of ecosystem services while 
simultaneously promoting sustainable land-use practices in areas where ecosystem services are limited.

Table 1 provides a framework for decision-making with regards to the prioritization of areas within a watershed based on the approach presented here: the combination of improving ecosystem service delivery and reducing environmental risks of degradation.

In the Martín Basin, restoration efforts in the southern region could focus on the protection, stabilization and enhancement of existing synergies between services in areas where service values are relatively low. Bennett et al. (2009) showed that when investments are made in securing regulating services, provisioning and cultural services also increase, resulting in an increased resilience of the local ecosystems. For this reason restoration actions should focus on increasing erosion control service by reestablishing or improving the shrub and forest ecosystems thereby stimulating ground water recharge, protecting important headwater areas and maintaining soil fertility, thereby increasing carbon sequestration, which will positively influence from microclimatic to global conditions.

In the northern lowland area of the Martín Basin, where the lowest values of soil fertility were found, a best management practice approach would ensure long-term provisioning of agriculturally derived benefits. The adoption of good agricultural practices, including conservation tillage and adaptation to future threats due to climate change, should be encouraged. Additional management practices could include the use of manure and biomass residues (e.g., straw mulching), which will help to improve soil organic carbon levels (Jones et al. 2005), thereby reducing soil and water losses (Su et al. 2007). The implementation of multi-crop rotation strategies would also increase the level of soil organic carbon (West and Post, 2002) and improve soil structure, making soils more resilient (Lal 1997). The establishment of leguminous forage crops on low productive areas would improve livestock production (Delgado 2000). This would require the use of native and adapted species to avoid potential negative impacts on the ecosystems.

Special attention must be given to mining areas because they are the major source of sediment due to the high erosion rates found in the basin (Trabucchi et al. 2012b). These mines have been restored using a variety of restoration techniques and strategies at different times (Moreno de-las Heras et al. 2008). The opportunity to create new services in restored areas exists and has been demonstrated on several restored mines in the Martín Basin that have been planted with crops and fruit trees. However, in order for these areas to be sustainable, best agricultural practices need to be adopted due to the high susceptibility of their soils to erosion and the very low soil organic carbon content. Furthermore, wetlands created in the old 
mine pits can provide multiple functions at a smaller scale, including recreation and education, and contribute multiple services at a larger/watershed scale, which could be accomplished in this semi-arid area through re-establishing a network of sites for biodiversity development (Moreno-Mateos et al. 2009).

This study shows that mapping multiple ecosystem services provides a useful framework for management and restoration planning at the watershed scale. Further progress for planning restoration at watershed scale should include social and economic aspects of ecosystem services.

\section{Conclusions}

This study presents an approach for incorporating the assessment of a bundle of ecosystem services and a key ecological degradation factor, soil erosion, into the management and the targeting of spatial restoration efforts at basin scale. A key limiting factor is the availability of data at an appropriate level of resolution. The selection of sites can be performed at watershed and sub-watershed scales, both for preservation of hotspots for ecosystem service provisioning and for prioritization of restoration sites. Ecosystem services need to be considered in conjunction with degradation maps to set realistic goals for restoration. In this study no additional socio-economic data have so far been included in the interpretation scheme. It is expected that the assimilation of such spatially explicit data layers may further increase interpretation capacities. This kind of assessment can be used as a first step decision-aid tool to assist policy makers to inform decisions for promoting the rational use of ecosystem services for human wellbeing. Mapping ecosystem services at a watershed scale provides a useful framework for planning land use; this approach is step forward to prioritize the ecological restoration and management of a territory made up of a mosaic of ecosystem types. 


\section{Acknowledgments}

The authors want to thank B. Reyers for inspiration and helpfulness and the research group CSIR,

Council for Scientific and Industrial Research of Stellenbosch (South Africa), especially D. le Maitre and J. Nel for their advice and patience and P. Ntshotsho for help with revising the manuscript. We tank M.P. Errea, J. Zabalza for the help with GIS analysis and E. Navarro for suggestions on improving the manuscript. This work was funded by Endesa S.A. through the collaborative agreement Endesa-CSIC for scientific research. M. Trabucchi was in receipt of a grant from the Board for Advanced Study, European Social Found, JAE-Doc, Ref. I3P-BPD-2006. This work is a contribution to the Labex OT-Med (no. ANR-11-LABX-0061) funded by the French Government «Investissements d'Avenir» program of the French National Research Agency (ANR) through the A*MIDEX project (no. ANR-11-IDEX-0001-02). 


\section{References}

ArcGis resource center (2012) Available online:http://help.arcgis.com/en/arcgisdesktop/10.0/help/index.html\#//009z000000wt000000.htm

Barbier EB, Koch EW, Silliman BR, et al. (2008) Coastal Ecosystem-Based Management with Nonlinear Ecological Functions and Values. Science 319:321 -323. doi: 10.1126/science.1150349

Bellot J, Bonet A, Sanchez JR, Chirino E (2001) Likely effects of land use changes on the runoff and aquifer recharge in a semiarid landscape using a hydrological model. Landsc Urban Plan 55:4153

Benayas JMR, Newton AC, Diaz A, Bullock JM (2009) Enhancement of Biodiversity and Ecosystem Services by Ecological Restoration: A Meta-Analysis. Science 325:1121-1124. doi: 10.1126/science. 1172460

Bennett EM, Peterson GD, Gordon LJ (2009) Understanding relationships among multiple ecosystem services. Ecol Lett 12:1394-1404. doi: 10.1111/j.1461-0248.2009.01387.x

Birch JC, Newton AC, Aquino CA, et al. (2010) Cost-effectiveness of dryland forest restoration evaluated by spatial analysis of ecosystem services. Proc Natl Acad Sci 107:21925-21930. doi: 10.1073/pnas.1003369107

Brabyn L, Mark DM (2011) Using viewsheds, GIS, and a landscape classification to tag landscape photographs. Appl Geogr 31:1115-1122. doi: 10.1016/j.apgeog.2011.03.003

Carpenter SR, Mooney HA, Agard J, et al. (2009) Science for managing ecosystem services: Beyond the Millennium Ecosystem Assessment. Proc Natl Acad Sci 106:1305 -1312. doi: 10.1073/pnas.0808772106

Coen LD, Brumbaugh RD, Bushek D, et al. (2007) Ecosystem services related to oyster restoration. Mar Ecol Prog Ser 341:303-307. doi: 10.3354/meps341303

Comín FA (2010) Ecological restoration: a global challenge. Cambridge Univ Pr

Comin FA, Nicolau JM, Trabucchi M, et al. (2009) Establishing priorities for the management and restoration of river basins with opencast coal mines. River Basin Manag V 315-326

Delgado Enguita I (2000) Base forrajera para el establecimiento de ganaderías de ovino en el secano cerealista. Institución Fernando el Católico

Dotterweich M (2013) The history of human-induced soil erosion: Geomorphic legacies, early descriptions and research, and the development of soil conservation-A global synopsis. Geomorphology 201:1-34. doi: 10.1016/j.geomorph.2013.07.021

Egoh B, Reyers B, Rouget M, et al. (2008) Mapping ecosystem services for planning and management. Agric Ecosyst Environ 127:135-140. doi: 10.1016/j.agee.2008.03.013

Forsyth G, Le Maitre D, O'Farrell P, van Wilgen B (2012) The prioritisation of invasive alien plant control projects using a multi-criteria decision model informed by stakeholder input and spatial data. J Environ Manage 103:51-57

Fu B, Wang S, Su C, Forsius M (2013) Linking ecosystem processes and ecosystem services. Curr Opin Environ Sustain 5:4-10. doi: 10.1016/j.cosust.2012.12.002 
García-Ruiz JM (2010) The effects of land uses on soil erosion in Spain: A review. CATENA 81:1-11. doi: 10.1016/j.catena.2010.01.001

García-Ruiz JM, Nadal-Romero E, Lana-Renault N, Beguería S (2013) Erosion in Mediterranean landscapes: Changes and future challenges. Geomorphology 198:20-36. doi: 10.1016/j.geomorph.2013.05.023

Gobin A, Jones R, Kirkby M, et al. (2004) Indicators for pan-European assessment and monitoring of soil erosion by water. Environ Sci Policy 7:25-38. doi: 10.1016/j.envsci.2003.09.004

Groffman P, Baron J, Blett T, et al. (2006) Ecological Thresholds: The Key to Successful Environmental Management or an Important Concept with No Practical Application? Ecosystems 9:1-13. doi: $10.1007 / \mathrm{s} 10021-003-0142-\mathrm{z}$

De Groot RS, Alkemade R, Braat L, et al. (2010) Challenges in integrating the concept of ecosystem services and values in landscape planning, management and decision making. Ecol Complex $7: 260-272$

De Groot RS, Wilson MA, Boumans RM. (2002) A typology for the classification, description and valuation of ecosystem functions, goods and services. Ecol Econ 41:393-408. doi: 10.1016/S0921-8009(02)00089-7

Guerrero-Campo J, Montserrat-Martí G (2004) Comparison of floristic changes on vegetation affected by different levels of soil erosion in Miocene clays and Eocene marls from Northeast Spain. Plant Ecol Former Veg 173:83-93. doi: 10.1023/B:VEGE.0000026331.85303.c8

Hauck J, Görg C, Varjopuro R, et al. (2013) "Maps have an air of authority”: Potential benefits and challenges of ecosystem service maps at different levels of decision making. Ecosyst Serv 4:2532. doi: 10.1016/j.ecoser.2012.11.003

Johnson NC (1995) Biodiversity in the balance: approaches to setting geographic conservation priorities. Biodiversity Support Program

Jones RJA, Hiederer R, Rusco E, Montanarella L (2005) Estimating organic carbon in the soils of Europe for policy support. Eur J Soil Sci 56:655-671. doi: 10.1111/j.1365-2389.2005.00728.x

Khatami S, Berndtsson R (2013) Watershed Restoration of Urmia Lake, Iran. Environ. Dev.

Kremen C, Ostfeld RS (2005) A call to ecologists: measuring, analyzing, and managing ecosystem services. Front Ecol Environ 3:540-548

Lal R (1997) Degradation and Resilience of Soils. Philos Trans R Soc Lond B Biol Sci 352:997-1010. doi: $10.1098 /$ rstb.1997.0078

Lal R (2013) Soils and Ecosystem Services. In: Lal R, Lorenz K, Hüttl RF, et al. (eds) Ecosyst. Serv. Carbon Sequestration Biosphere. Springer Netherlands, pp 11-38

Loomis J, Kent P, Strange L, et al. (2000) Measuring the total economic value of restoring ecosystem services in an impaired river basin: results from a contingent valuation survey. Ecol Econ 33:103-117

Maes J, Egoh B, Willemen L, et al. (2012) Mapping ecosystem services for policy support and decision making in the European Union. Ecosyst Serv 1:31-39. doi: 10.1016/j.ecoser.2012.06.004 
Le Maitre DC, Milton SJ, Jarmain C, et al. (2007) Linking ecosystem services and water resources: landscape-scale hydrology of the Little Karoo. Front Ecol Environ 5:261-270. doi: 10.1890/1540-9295(2007)5[261:LESAWR]2.0.CO;2

Martín-López B, Gómez-Baggethun E, Lomas PL, Montes C (2009) Effects of spatial and temporal scales on cultural services valuation. J Environ Manage 90:1050-1059. doi: 10.1016/j.jenvman.2008.03.013

Matson PA, Parton WJ, Power AG, Swift MJ (1997) Agricultural Intensification and Ecosystem Properties. Science 277:504-509. doi: 10.1126/science.277.5325.504

McMichael A, Scholes R, Hefny M, et al. (2005) Linking ecosystem services and human well-being. Doris Capistrano Cristan Samper K Ecosyst Eds Ecosyst Hum Well- 4:43-60.

Menz MHM, Dixon KW, Hobbs RJ (2013) Hurdles and Opportunities for Landscape-Scale Restoration. Science 339:526-527. doi: 10.1126/science.1228334

Mitsch WJ, Day JW, Gilliam JW, et al. (2001) Reducing Nitrogen Loading to the Gulf of Mexico from the Mississippi River Basin: Strategies to Counter a Persistent Ecological Problem. BioScience 51:373-388. doi: 10.1641/0006-3568(2001)051[0373:RNLTTG]2.0.CO;2

Moberg F, Rönnbäck P (2003) Ecosystem services of the tropical seascape: interactions, substitutions and restoration. Ocean Coast Manag 46:27-46

Montero M M, Montagnini F Modelos alométricos para la estimación de biomasa de diez especies nativas en plantaciones en la región Atlántica de Costa Rica. Recur. Nat. Ambiente CATIE Ago 2005

Moreno-de las Heras M, Espigares T, Merino-Martín L, Nicolau JM (2011) Water-related ecological impacts of rill erosion processes in Mediterranean-dry reclaimed slopes. Catena 84:114-124. doi: $10.1016 /$ j.catena.2010.10.010

Moreno-de las Heras M, Nicolau JM, Espigares T (2008) Vegetation succession in reclaimed coal-mining slopes in a Mediterranean-dry environment. Ecol Eng 34:168-178

Moreno-Mateos D, Pedrocchi C, Comín FA (2009) Avian communities' preferences in recently created agricultural wetlands in irrigated landscapes of semi-arid areas. Biodivers Conserv 18:811-828

Myers N (1996) Environmental services of biodiversity. Proc Natl Acad Sci 93:2764 -2769.

Naidoo R, Ricketts TH (2006) Mapping the Economic Costs and Benefits of Conservation. PLoS Biol 4:e360. doi: 10.1371/journal.pbio.0040360

Nelson E, Mendoza G, Regetz J, et al. (2009) Modeling multiple ecosystem services, biodiversity conservation, commodity production, and tradeoffs at landscape scales. Front Ecol Environ 7:411. doi: doi:10.1890/080023

O'Farrell PJ, Reyers B, Maitre DC, et al. (2010) Multi-functional landscapes in semi arid environments: implications for biodiversity and ecosystem services. Landsc Ecol 25:1231-1246. doi: 10.1007/s10980-010-9495-9

Palmer MA, Filoso S (2009) Restoration of ecosystem services for environmental markets. Science 325:575-576. doi: 10.1126/science.1172976

Palmer MA, Filoso S, Fanelli RM From ecosystems to ecosystem services: Stream restoration as ecological engineering. Ecol Eng. doi: 10.1016/j.ecoleng.2013.07.059 
Power AG (2010) Ecosystem services and agriculture: tradeoffs and synergies. Philos Trans R Soc B Biol Sci 365:2959 -2971. doi: 10.1098/rstb.2010.0143

Quinton JN, Edwards GM, Morgan RPC (1997) The influence of vegetation species and plant properties on runoff and soil erosion: results from a rainfall simulation study in south east Spain. Soil Use Manag 13:143-148. doi: 10.1111/j.1475-2743.1997.tb00575.x

Renard KG, Foster GR, Weesies GA, et al. (1997) Predicting soil erosion by water: a guide to conservation planning with the revised universal soil loss equation (RUSLE). Agric. Handb. Wash.

Renard KG, Foster GR, Weesies GA, Porter JP (1991) RUSLE: Revised universal soil loss equation. J Soil Water Conserv 46:30-33

Reyers B, O’Farrell PJ, Cowling RM, et al. (2009) Ecosystem services, land-cover change, and stakeholders: finding a sustainable foothold for a semiarid biodiversity hotspot.

Rojo L (1990) Plan nacional de restauración hidrológico-forestal y control de la erosión. Memoria

Roni P, Beechie TJ, Bilby RE, et al. (2002) A Review of Stream Restoration Techniques and a Hierarchical Strategy for Prioritizing Restoration in Pacific Northwest Watersheds. North Am J Fish Manag 22:1-20. doi: 10.1577/1548-8675(2002)022<0001:AROSRT>2.0.CO;2

Salvati L, Bajocco S (2011) Land sensitivity to desertification across Italy: Past, present, and future. Appl Geogr 31:223-231. doi: 10.1016/j.apgeog.2010.04.006

Samraj P, Sharda VN, Chinnamani S, et al. (1988) Hydrological behaviour of the Nilgiri sub-watersheds as affected by bluegum plantations, part I. The annual water balance. J Hydrol 103:335-345. doi: $10.1016 / 0022-1694(88) 90142-4$

Schneiders A, Van Daele T, Van Landuyt W, Van Reeth W (2012) Biodiversity and ecosystem services: Complementary approaches for ecosystem management? Ecol Indic 21:123-133. doi: 10.1016/j.ecolind.2011.06.021

Sophocleous M (2002) Interactions between groundwater and surface water: the state of the science. Hydrogeol J 10:52-67. doi: 10.1007/s10040-001-0170-8

Su C, Fu B (2013) Evolution of ecosystem services in the Chinese Loess Plateau under climatic and land use changes. Glob Planet Change 101:119-128. doi: 10.1016/j.gloplacha.2012.12.014

Su S, Xiao R, Jiang Z, Zhang Y (2012) Characterizing landscape pattern and ecosystem service value changes for urbanization impacts at an eco-regional scale. Appl Geogr 34:295-305. doi: 10.1016/j.apgeog.2011.12.001

Swift MJ, Izac A-MN, van Noordwijk M (2004) Biodiversity and ecosystem services in agricultural landscapesâ€"'are we asking the right questions? Agric Ecosyst Environ 104:113-134. doi: 10.1016/j.agee.2004.01.013

Tallis H, Kareiva P, Marvier M, Chang A (2008) An ecosystem services framework to support both practical conservation and economic development. Proc Natl Acad Sci 105:9457

Trabucchi M, Ntshotsho P, O’Farrell P, Comín FA (2012a) Ecosystem service trends in basin-scale restoration initiatives: A review. Journal of Environmental Management 111:18-23. doi: 10.1016/j.jenvman.2012.06.040 
Trabucchi M, Puente C, Comin FA, et al. (2012b) Mapping erosion risk at the basin scale in a Mediterranean environment with opencast coal mines to target restoration actions. Reg Environ Change. doi: 10.1007/s10113-012-0278-5

Troy A, Wilson MA (2006) Mapping ecosystem services: practical challenges and opportunities in linking GIS and value transfer. Ecol Econ 60:435-449

Viglizzo EF, Paruelo JM, Laterra P, Jobbágy EG (2012) Ecosystem service evaluation to support land-use policy. Agric Ecosyst Environ 154:78-84. doi: 10.1016/j.agee.2011.07.007

Wallace KJ (2007) Classification of ecosystem services: Problems and solutions. Biol Conserv 139:235246. doi: 10.1016/j.biocon.2007.07.015

West TO, Post WM (2002) Soil Organic Carbon Sequestration Rates by Tillage and Crop Rotation. Soil Sci Soc Am J 66:1930. doi: 10.2136/sssaj2002.1930

Winjum JK, Schroeder PE (1997) Forest plantations of the world: their extent, ecological attributes, and carbon storage. Agric For Meteorol 84:153-167. doi: 10.1016/S0168-1923(96)02383-0

Yuan J, Fang W, Fan L, et al. (2006) Soil Formation and Vegetation Establishment on the Cliff Face of Abandoned Quarries in the Early Stages of Natural Colonization. Restor Ecol 14:349-356. doi: 10.1111/j.1526-100X.2006.00143.x

Zalewski M, Wagner-Lotkowska I, UNESCO (2004) Integrated watershed mangement: ecohydrology \& phytotechnology. Manual. http://bases.bireme.br/cgibin/wxislind.exe/iah/online/?IsisScript=iah/iah.xis\&src=google\&base=REPIDISCA\&lang=p\&ne xtAction=lnk\&exprSearch=30275\&indexSearch=ID. Accessed 16 Dec 2013

Zhang W, Ricketts TH, Kremen C, et al. (2007) Ecosystem services and dis-services to agriculture. Ecol Econ 64:253-260. doi: 10.1016/j.ecolecon.2007.02.024 
Figure captions:

Title: Study area and land use

Fig. 1 (Left), Map of the Martín River Basin showing its hydrological network, and the upper (South) part and the lower (North) part of the Basin. (Right), Land use map of Martín River Basin

Title: Spatial distribution of ecosystem services

Fig. 2 Overlap of ecosystem services in the basin (left) and hotspots (right)

Title: Spatial distribution of hot spot ecosystem services

Fig. 3 Number of overlap of ecosystem services per sub-watershed scale, (left) and number of overlapping hotspot services per sub-watershed

Title: Degradation maps at watershed scale and sub-watershed scale

Fig. 4 Erosion level on the Martín Basin (left) and degradation at sub-watershed scale 
Tab. 1 Combined ecosystem services delivery and environmental risk criteria for establishing priority areas for restoration.

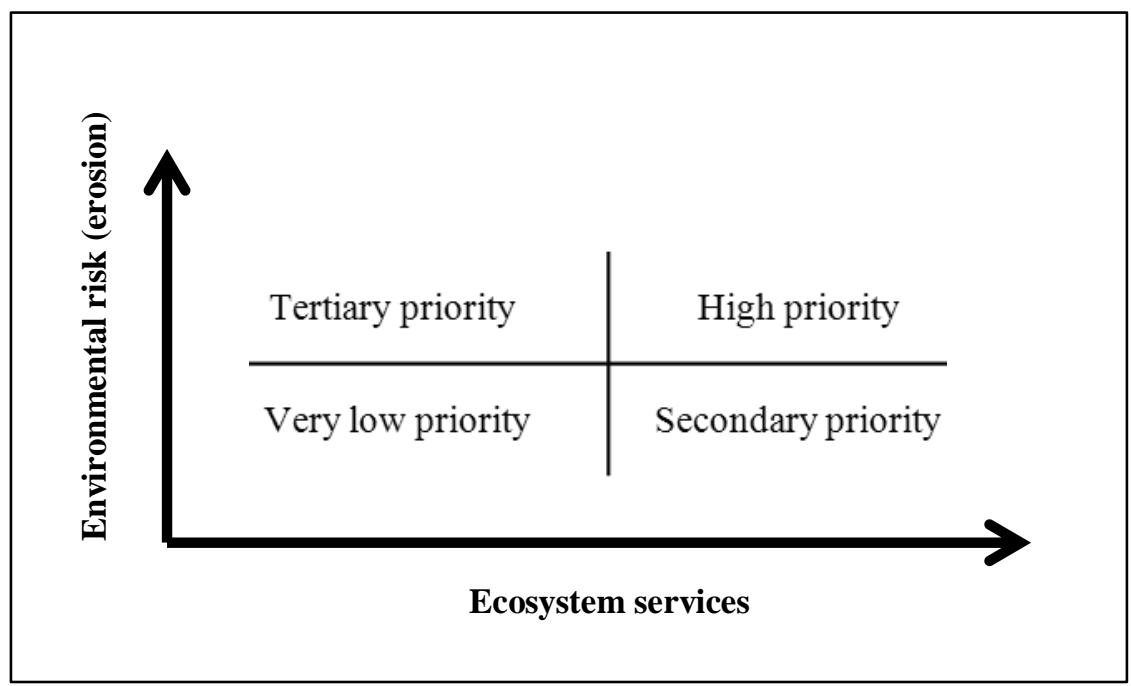


Tab. 2 Percentage of the Martín Basin area where the ecosystem services listed are delivered. Between brackets is the percentage of the basin area where these services are delivered as hotspots (with high and very high values for the service)

\begin{tabular}{lc} 
Ecosystem service & Area \\
\hline Water flow regulation & $79.5(42.4)$ \\
Surface water supply & $67(7.3)$ \\
Soil accumulation & $61.5(19.4)$ \\
Recreation/Ecotourism & $36(22)$ \\
Carbon storage & $21.1(2.4)$ \\
Soil retention & $40.2(19)$ \\
\hline
\end{tabular}


Click here to download Table: Table_3revised.docx

Tab. 3 Proportional (\%) overlap of ecosystem services in the basin and hotspots (hotspots in brackets)

\begin{tabular}{|c|c|c|c|c|c|}
\hline & $\begin{array}{l}\text { Soil } \\
\text { accumulation }\end{array}$ & $\begin{array}{l}\text { Carbon } \\
\text { storage }\end{array}$ & Soil retention & $\begin{array}{l}\text { Water flow } \\
\text { regulation }\end{array}$ & Surface water \\
\hline Carbon storage & $21.1(1.26)$ & & & & \\
\hline $\begin{array}{l}\text { Soil retention } \\
\text { Water flow }\end{array}$ & $10(5.1)$ & $18.7(2)$ & & & \\
\hline regulation & $61.1(16.3)$ & $21(2.23)$ & 38 (13.2) & & \\
\hline Surface water & $59.4(4.4)$ & $20.7(0.35)$ & $3.5(1.95)$ & $65(6.75)$ & \\
\hline Tourism & $13.6(4.3)$ & $6.8(0.18)$ & $10(4.5)$ & $22,1(11.5)$ & $17.1(5.6)$ \\
\hline
\end{tabular}




\section{Figure 1 Left}

Click here to download high resolution image

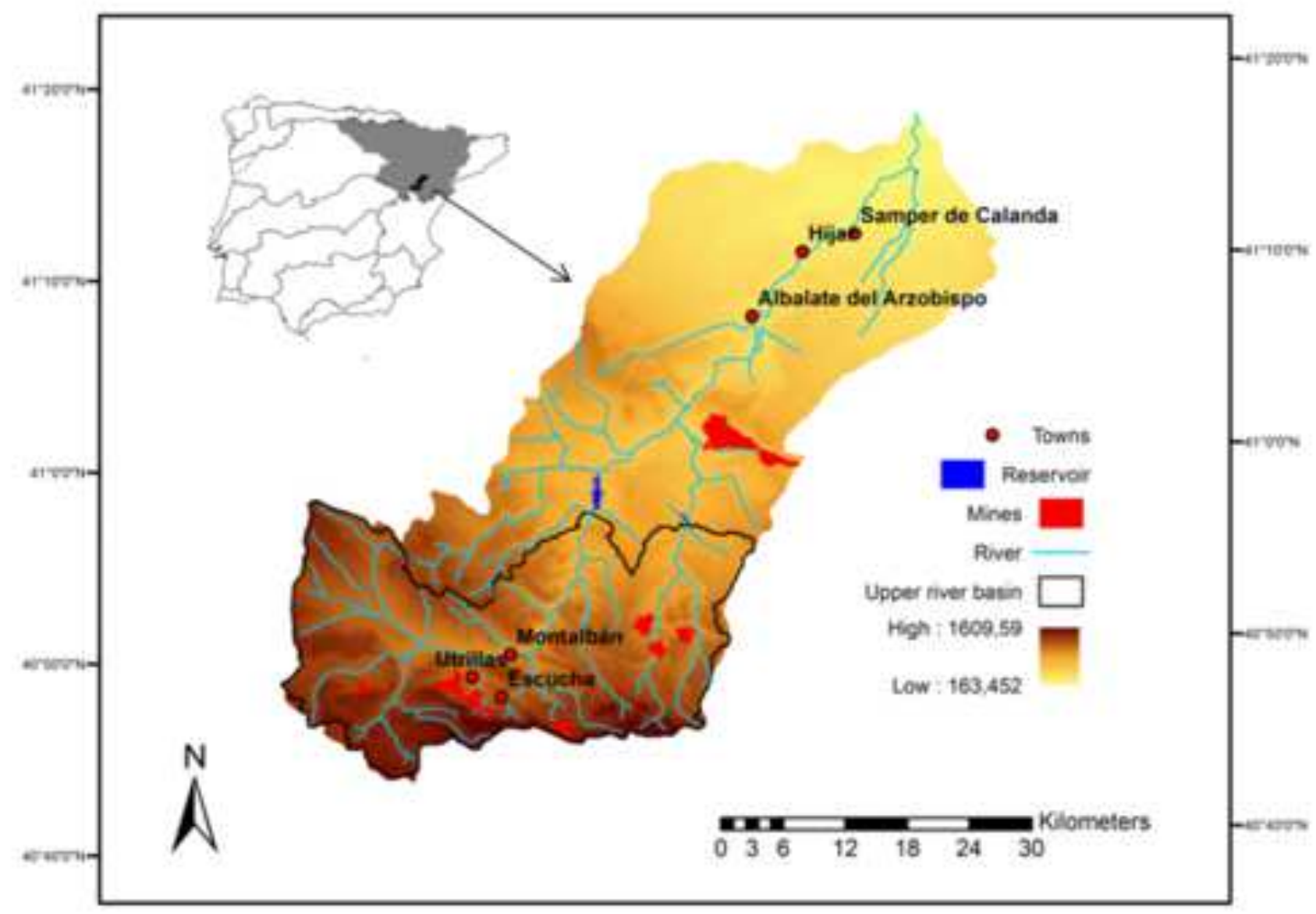


Figure1 Right

Click here to download high resolution image

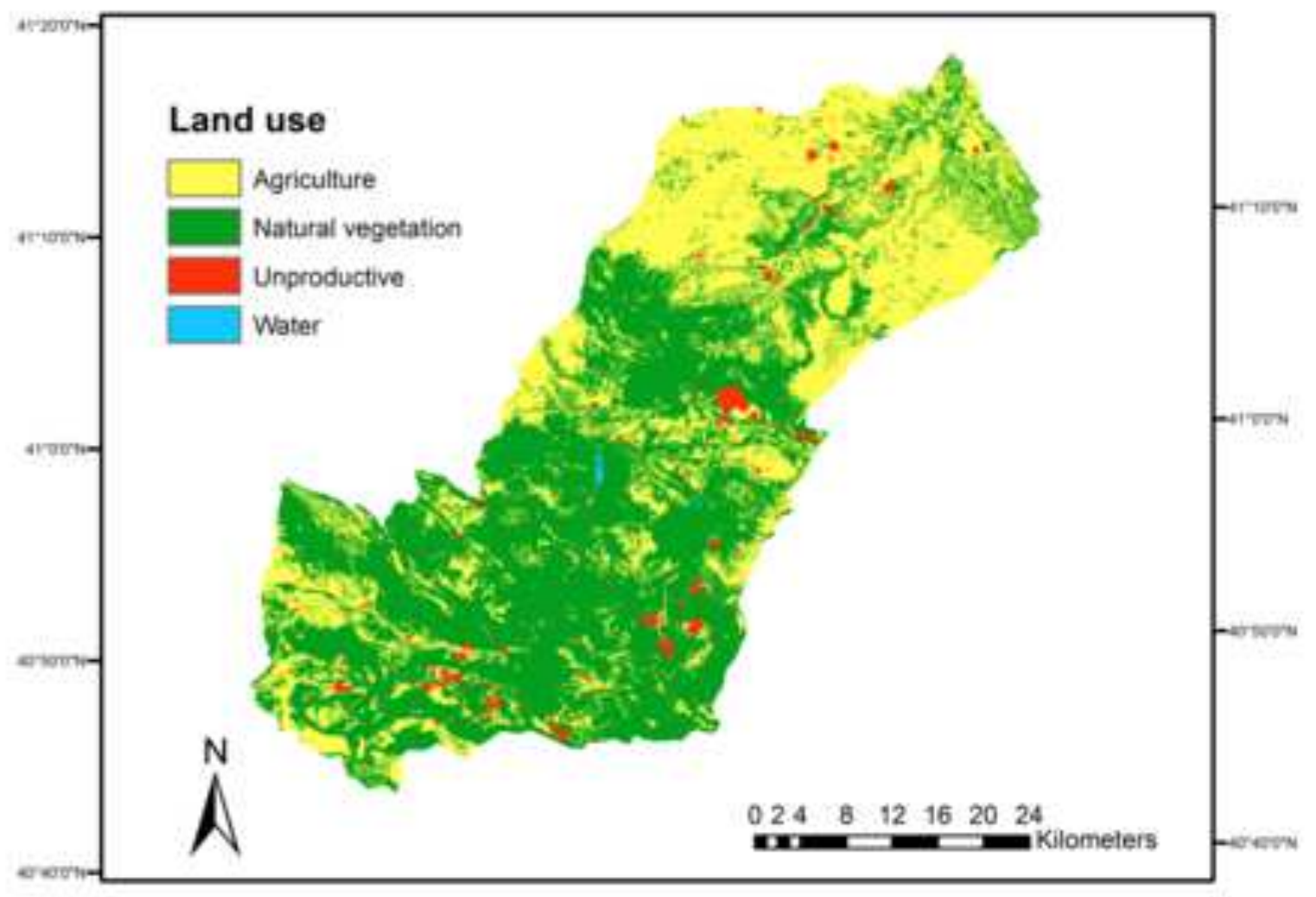


Figure2 Left
Click here to download high resolution image

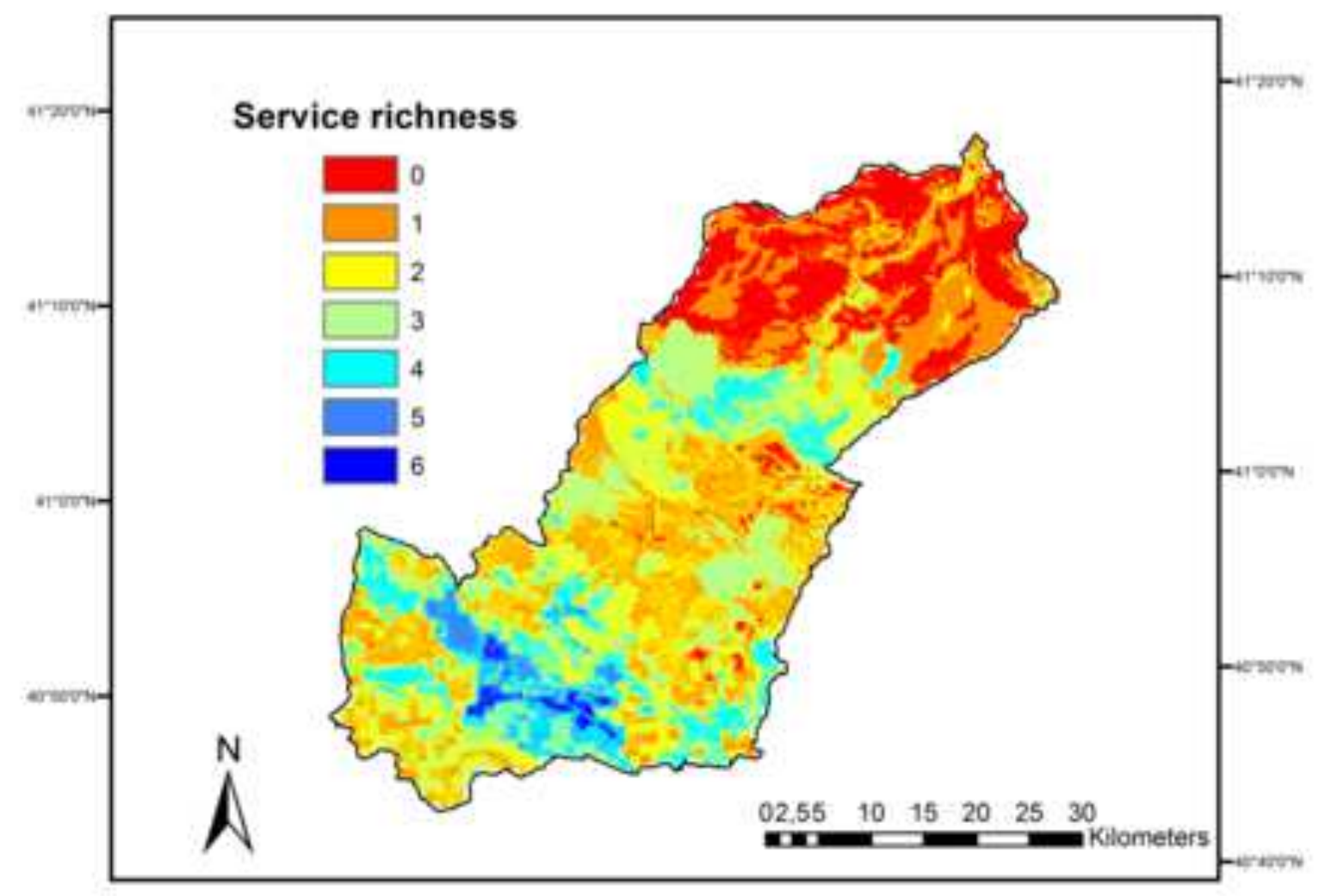


Figure2 Right
Click here to download high resolution image

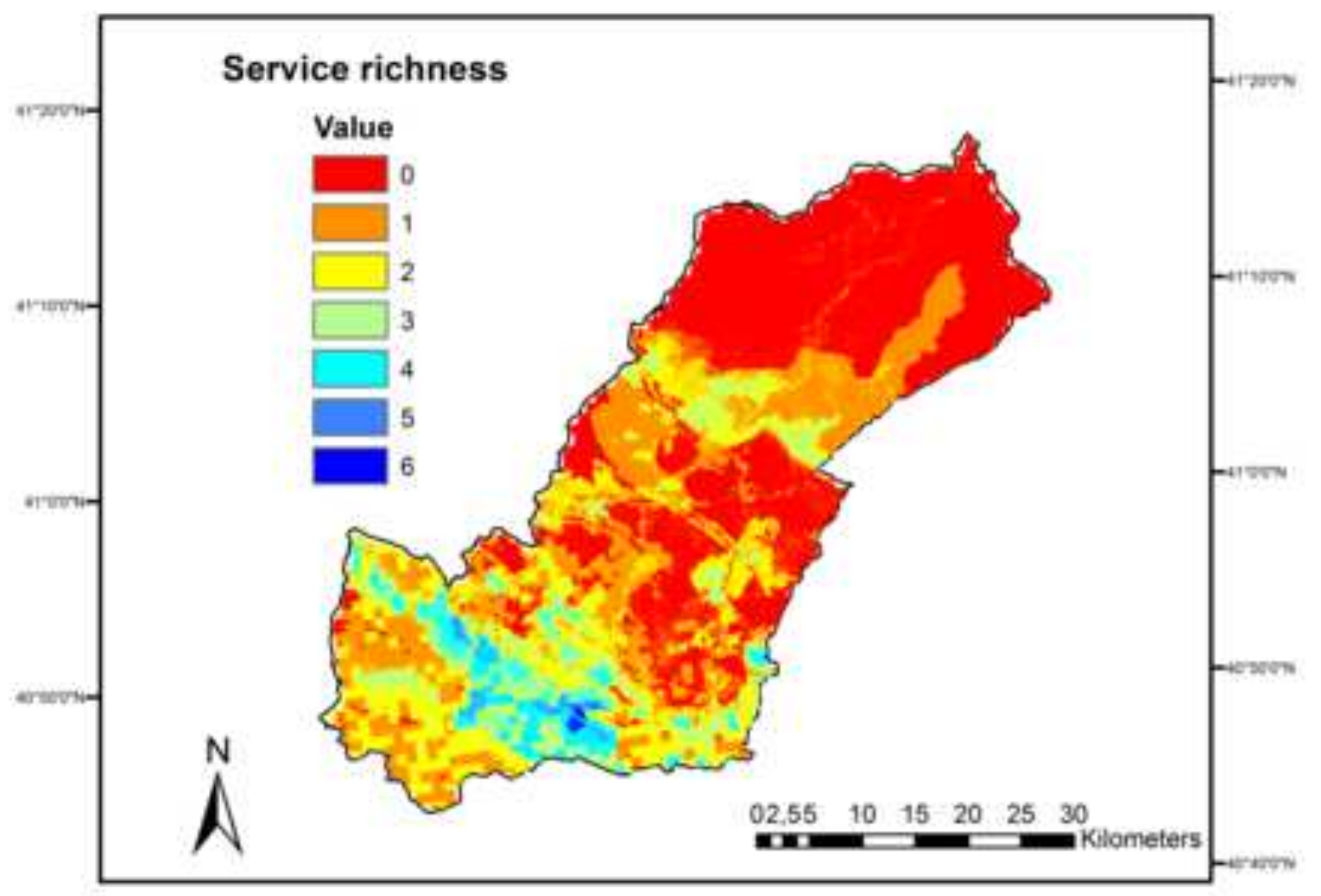


Figure3 Left

Click here to download high resolution image

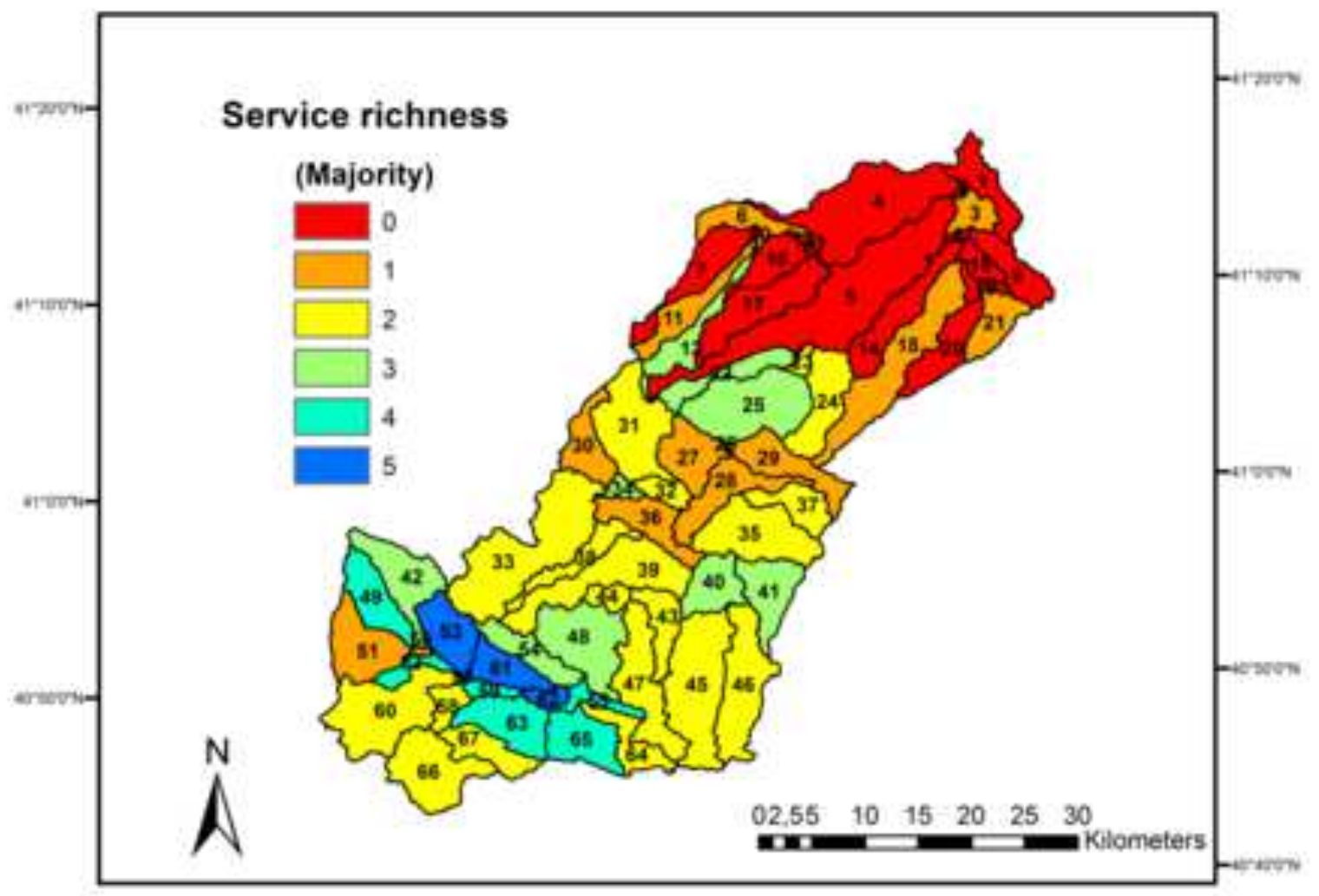


Figure3 Right

Click here to download high resolution image

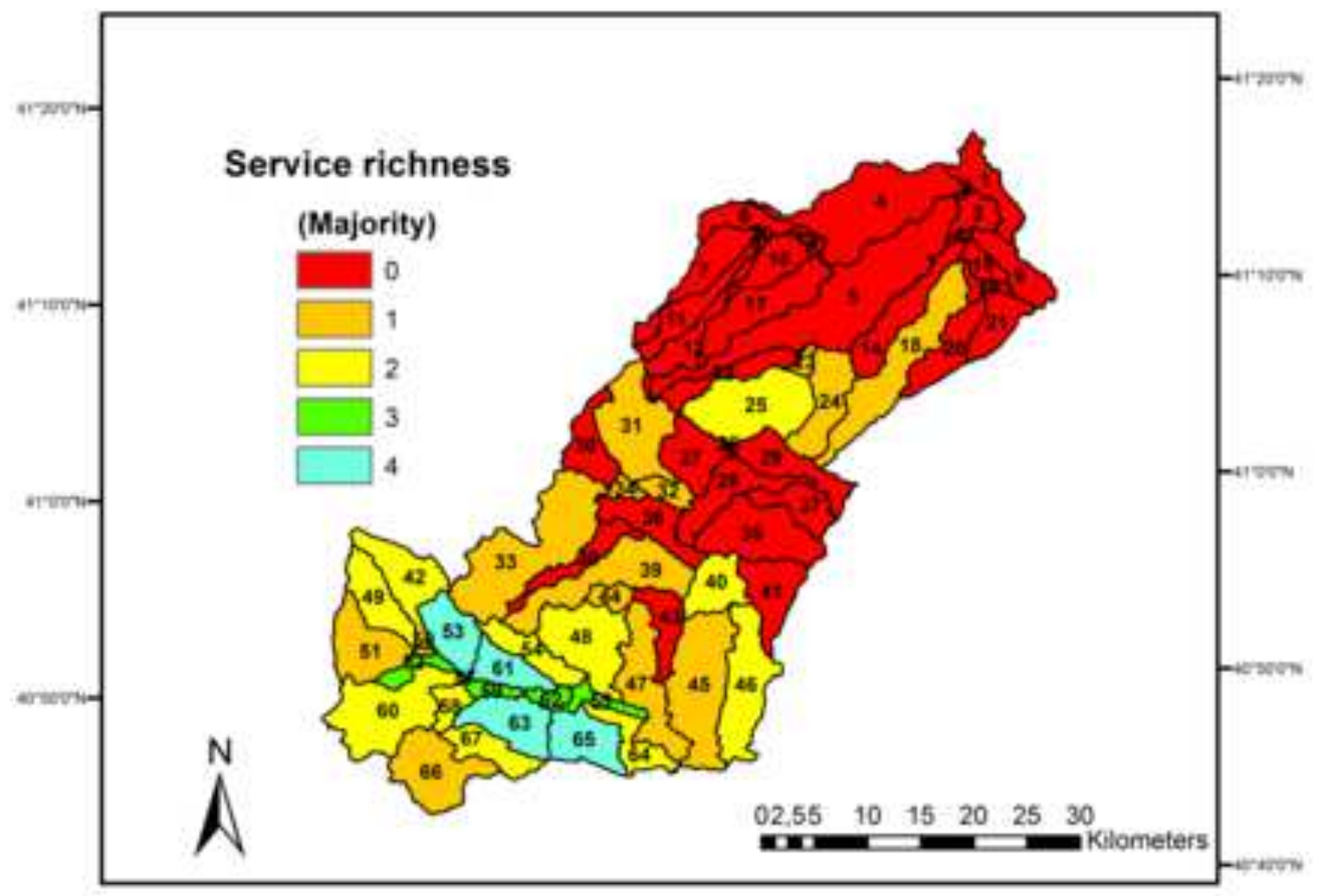


Figure4 Left

Click here to download high resolution image

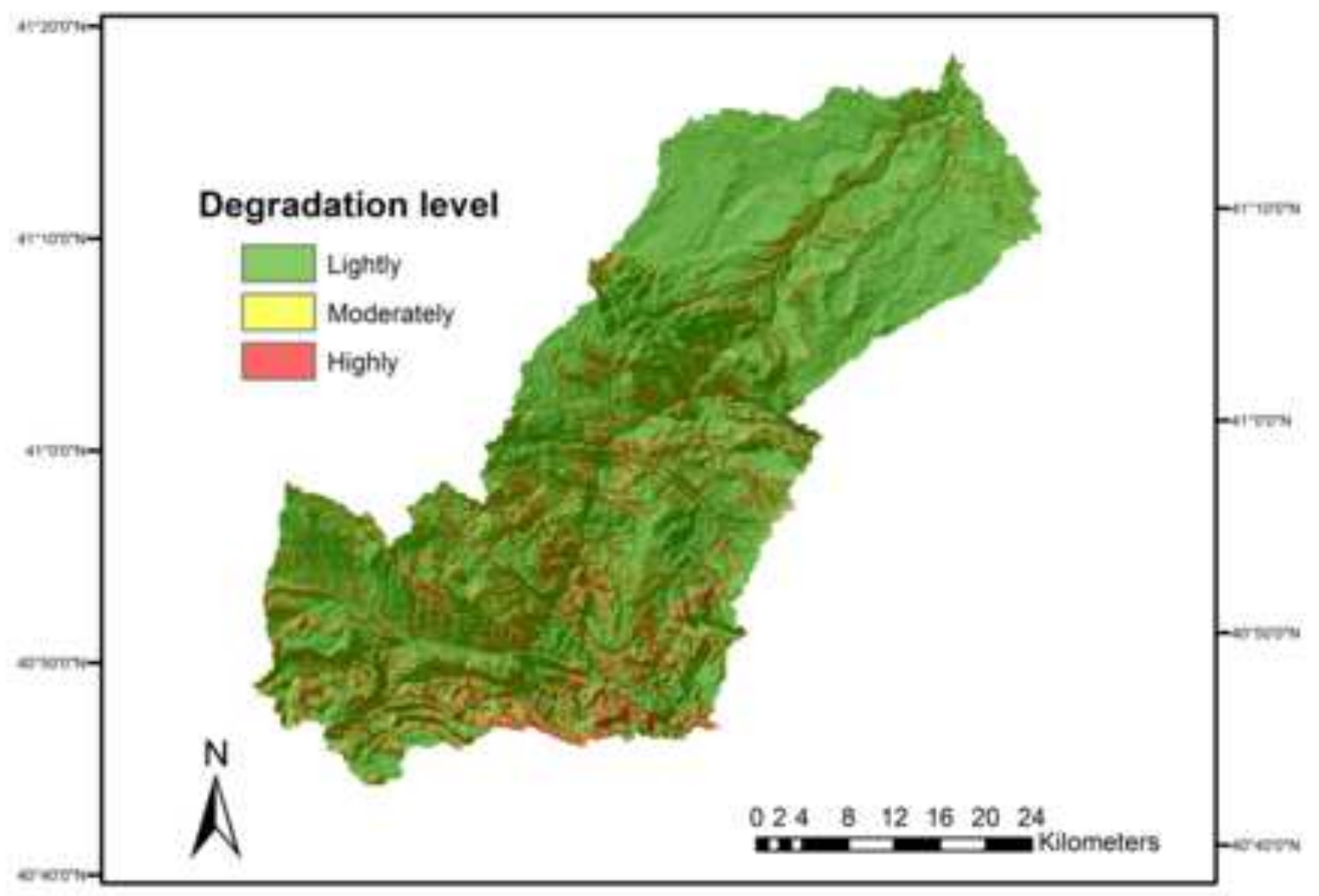




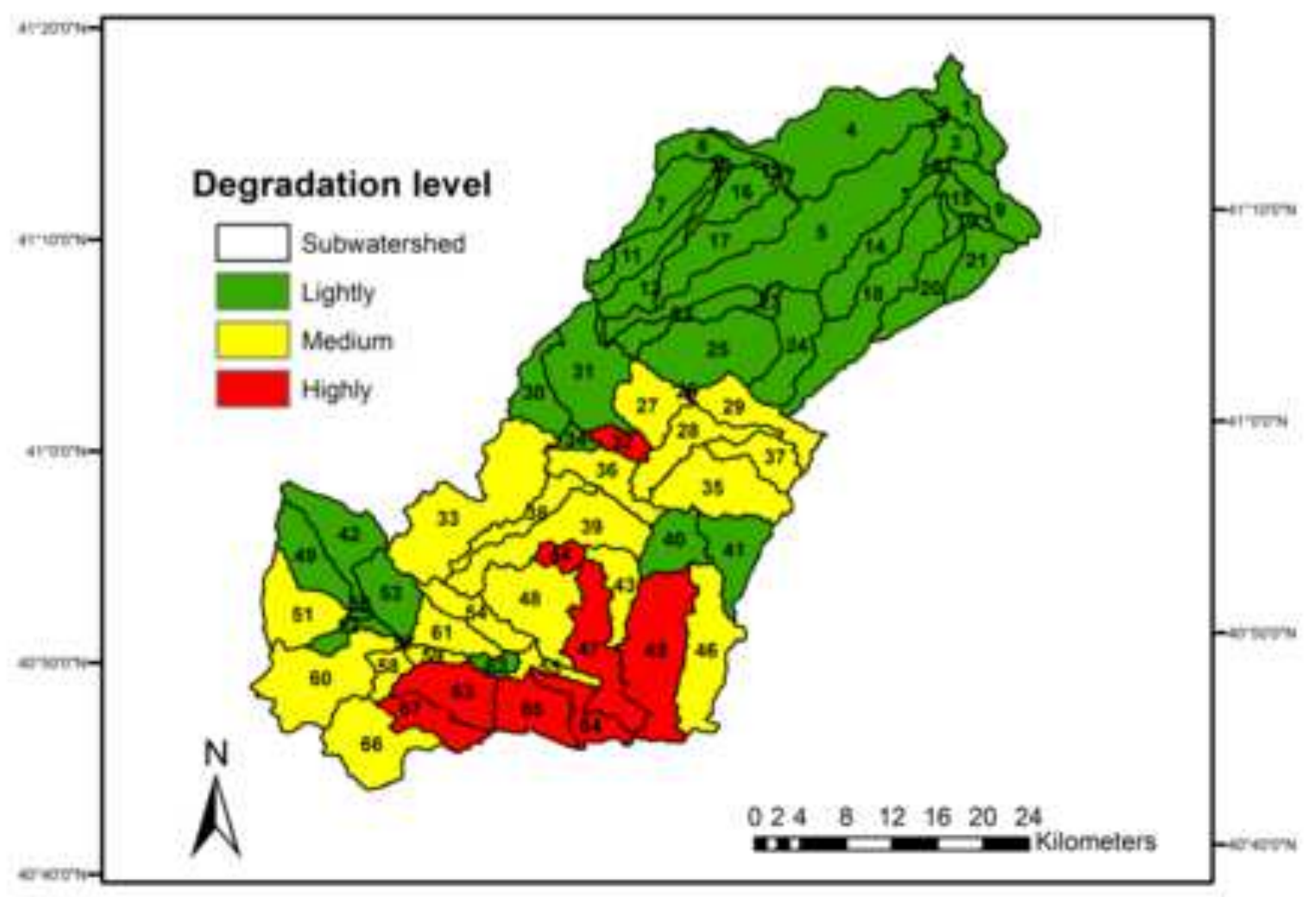


Supporting online material for

Mapping ecological processes and ecosystem services for prioritizing restoration efforts in a semiarid Mediterranean river basin

Appendix 1

This document includes:

Materials and Methods

References 


\section{Materials and Methods}

\section{Carbon storage}

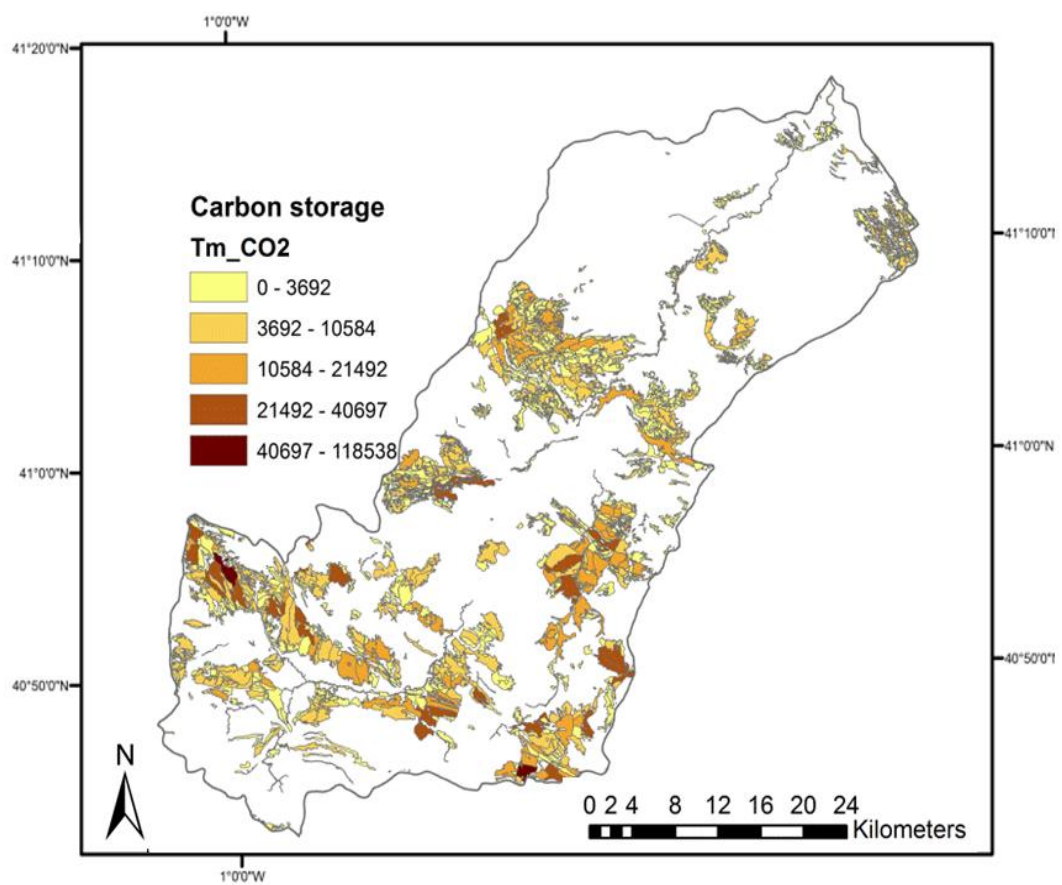

\section{Potential surface water supply}

We used runoff data extracted with the SIMPA model (Integrated System for Rainfall-Runoff Modelling) (Estrela and Quintas 1996; Estrela et al. 1999) for assessing surface water supply. This is a distributed hydrological model used for evaluating and mapping areas for delivering water supplies across Spain and is expressed in $\mathrm{mm}_{\text {year }}{ }^{-1}$ per $1 \mathrm{~km}^{2}$ cell-size resolution (Álvarez et al. 2005). The input data for the model were temperature, average monthly rainfall and potential evapotranspiration. Output data were the actual runoff, which included surface, underground and total.

Raster layers obtained were available monthly from October 1940 until September 2010 (http://servicios2.marm.es/sia/visualizacion/descargas/capas.jsp\#RASTER_AES). 


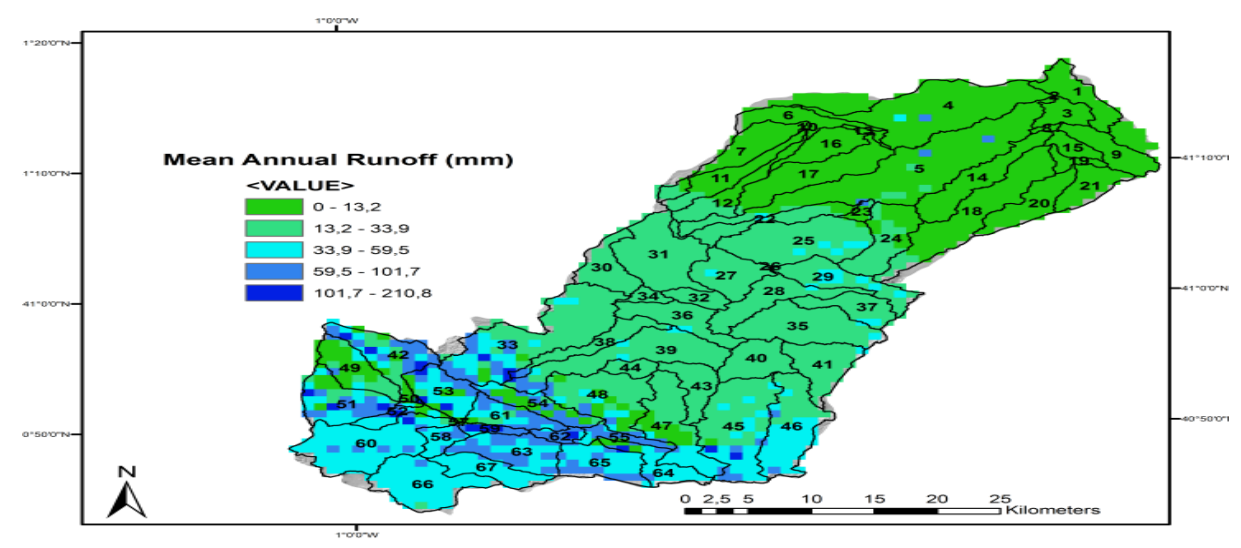

Wetlands are neither a key ecosystem nor are they relevant areas in the Martín Basin. The few existing wetlands occupy less than $1 \%$ of the basin area, are located in the depressed areas of restored mine zones and were created in previously non-existing wetland sites only 5-10 years ago, which is not a long enough period of time to have developed the relevant ecological characteristics required to be considered for ecosystem service valuation for this type of created ecosystem (Moreno-Mateos et al. 2012).

\section{Water runoff control}

Recharge maps for the basin were downloaded from the Confederación Hidrografica del Ebro (http://iber.chebro.es/sitebro/sitebro.aspx)

Input data: the daily means of precipitation and temperature at the meteorological stations in the area, 1:200,000 map of permeability of the substrate (Abad Fernández et al. 1980), land-use map (Corine Land Cover 2000 Spain) and digital terrain model of the Ebro Basin with a cell size of $30 \mathrm{~m}$ to calculate the slope of the terrain. Curve Number (Slack and Welch 1980) map of the Ebro Basin in raster format with a cell size of $350 \mathrm{~m}$. 


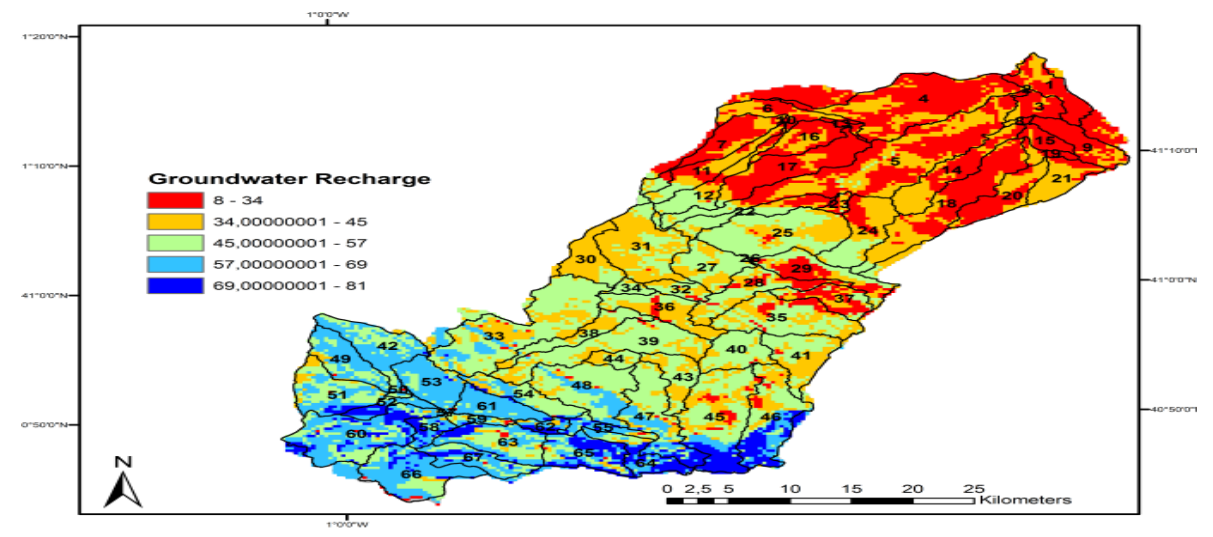

Runoff was calculated using the following procedure: for each day, the cumulative precipitation for the previous five days was calculated and the climate period of the year was determined (October-March wet and April to September dry); from these data and the accumulated rainfall, we established the type of correction to be applied to the curve number (Slack and Welch 1980). In the final steps, we assessed the runoff and the infiltration by the algorithms 1 and 2, which simplified the assumptions used by Thornthwaite and Mather (1957) for soil hydro-balance.

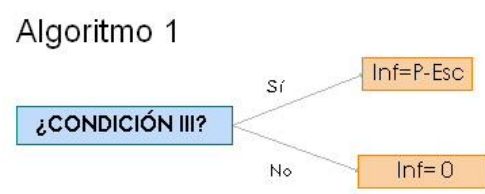

Algoritmo 2

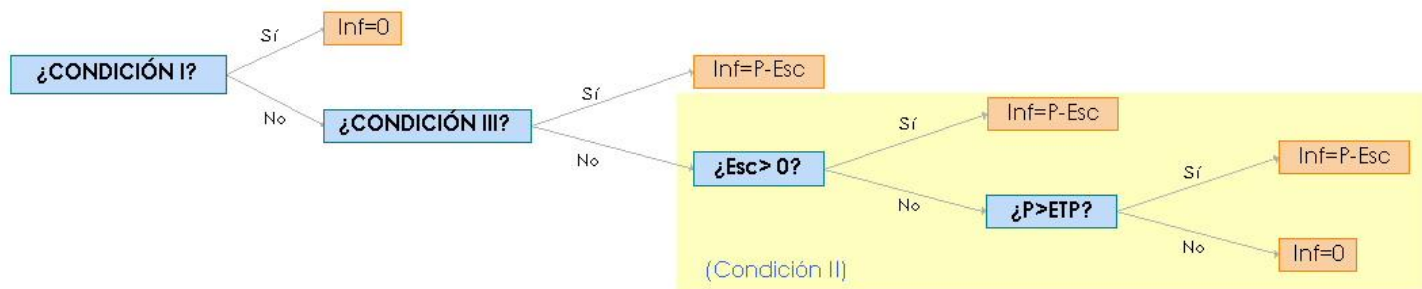


Output data: Infiltration raster map, expressed in $\mathrm{mm} /$ year discretized in a raster map expressed in $\mathrm{mm}$ year $^{-1}$ per $350 \times 350$ cell size resolution

\section{Soil retention}

Following the method of Egoh et al. (2008), soil retention was mapped as a function of vegetation cover density and soil erosion risk. Trabucchi et al. (2012) mapped and classified soil erosion risk according to five classes, from very low to very high and expressed in $\mathrm{tha}^{-1} \mathrm{yr}^{-1}$ for the study area at a resolution of 20 m cell size using the RUSLE model (Renard et al. 1997). Quinton et al. (1997), found that a decrease in soil loss was particularly marked as cover density increased from 0 to $30 \%$; as the vegetation $\%$ cover increased, the variation diminished, indicating that there was little difference in the soil loss when the vegetation cover exceeded $70 \%$. For the extrapolation of vegetation cover density, we used the cover factor of the RUSLE model (Renard et al. 1997) called C factor, which is the cover-management term, with the subfactors consisting of prior land use, crop canopy and surface cover (Renard et al. 1991). Trabucchi et al. (2012) applied to the study area the model using Genetic Programming Vegetation Index (GPVI) (Puente et al. 2011) to extract the cover factor, which evaluates vegetation land cover ranging from $0.45-1$ and is part of the RUSLE model formula.

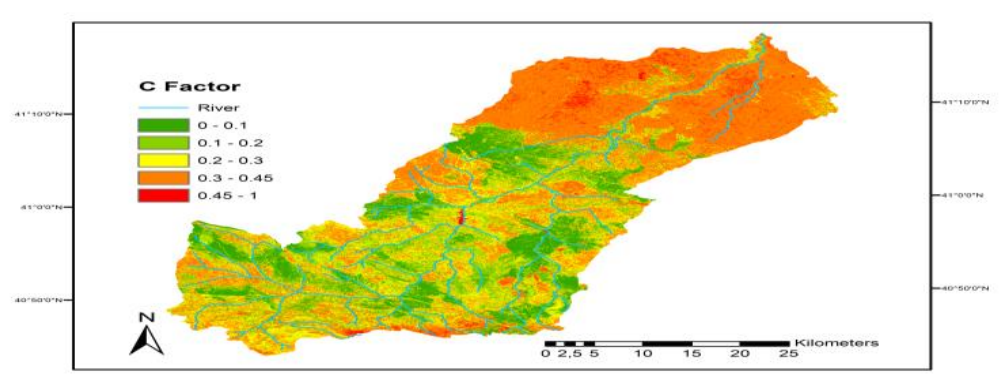

Calculations of vegetation Cover Density (CD) were extrapolated from the $\mathrm{C}$ factor. Soils that are constantly tilled or otherwise disturbed have maximum potential for erosion $(\mathrm{C}=1)$. Any type of cover 
shields soil, impedes erosion and reduces C. Soil that has not been recently disturbed "crusts over"' and has a nominal $\mathrm{C}$ of 0.45 . Live or dead vegetation and rocks reduce $\mathrm{C}$ (Smith et al. 2007). By simple algebra, we calculated $\mathrm{CD}$ as: $\mathrm{CD}=1.0-(1 / 0.45) \mathrm{C}=1.0-2.22 \mathrm{C}$. This is an empirical estimate of CD based on the end-member extreme cases and includes vegetation cover effects from both ground and canopy cover (including live and dead material).

Based on these data, vegetation cover density was sorted into three classes: $0-30 \%, 30-70 \%$ and $>70 \%$. Maps of soil retention services were created by extracting the congruence areas among vegetation cover density maps that had between 0 and $30 \%$ cover density and soil five erosion thresholds rates. Based on these data, vegetation cover densities were distributed in three classes: $0-30 \%, 30-70 \%$ and $70-100 \%$. RUSLE gives $\mathrm{tha}^{-1}$ year ${ }^{-1}$ of soil loss. The erosion values were combined with the percentage of plant cover to produce a range of relative value combinations (Figure below). Areas with vegetation cover greater than $30 \%$ and classified as having a very low to low erosion value were defined as having a potential to retain soil. A soil retention hotspot was defined as having a plant cover density greater than $70 \%$ with very low to low erosion values. Zones with cover densities of less than $30 \%$ and high to very high soil erosion values were extracted and identified as erosion-prone areas. In these areas, the use of best practices will be essential to prevent irreversible degradation of the soil. Furthermore, an assumption was made that the potential for soil retention is relatively low in areas with low vegetation cover.

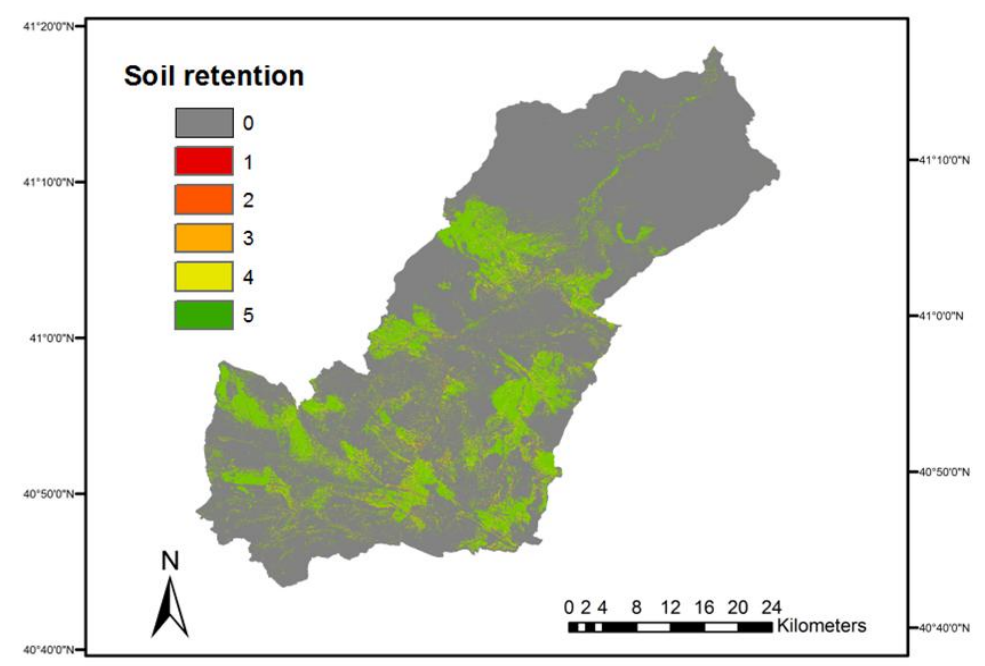




\section{Literature cited}

Abad Fernández J, Ayala Carcedo FJ, Pernía Llera JM (1980) Large scale, 1:1.000-1:5.000, geotechnical mapping by the Instituto Geologico y Minero de Espana, IGME (Spanish Geological and Mining Institute), for industrial and urban planning. Bulletin of the International Association of Engineering Geology 21:83-91.

Álvarez J, Sánchez A, Quintas L (2005) SIMPA, a GRASS based tool for Hydrological Studies. International Journal of Geoinformatics, 1(1), 13-20.

Estrela T, Cabezas Calvo-Rubio F, Estrada Lorenzo F (1999) La evaluación de los recursos hídricos en el Libro Blanco del Agua en España. Ingeniería del agua, (6), 2.

Estrela T, Quintas L (1996) The integrated precipitation-runoff modelling system, SIMPA. Ingenieria Civil, (104), 43-52.

Moreno-Mateos D, et al (2012) Structural and functional loss in restored wetland ecosystems. PLoS biology 10(1), p.e1001247.

Puente C, Olague G, Smith SV, Bullock SH, Hinojosa-Corona A, González-Botello MA (2011) A genetic programming approach to estimate vegetation cover in the context of soil erosion assessment. Photogrammetric Engineering \& Remote Sensing 77, 4.

Quinton JN, Edwards GM, Morgan RPC (1997) The influence of vegetation species and plant properties on runoff and soil erosion: results from a rainfall simulation study in south east Spain. Soil Use and Management, 13 (3), 143-148.

Renard KG et al (1997) Predicting soil erosion by water: a guide to conservation planning with the revised universal soil loss equation (RUSLE). Agriculture Handbook (Washington), (703).

Renard Kenneth G (1991) RUSLE: Revised universal soil loss equation. Journal of Soil and Water Conservation, 46 (1), 30-33.

Slack R, Welch R (1980) Soil conservation service runoff curve number estimates from Landsat Data1. JAWRA Journal of the American Water Resources Association 16(5), 887-893. 
Trabucchi M, et al (2012) Mapping erosion risk at the basin scale in a Mediterranean environment with opencast coal mines to target restoration actions. Regional Environmental Change 12 (4), 675687.

EEA-ETC/TE (2002) CORINE Land Cover update. IandCLC2000 project, Technical

Guidelines,available online: (http://terrestrial.eionet.eu.int). 